\title{
The Western Spread of Permic Hydronyms
}

The present study describes ancient Permian settlement history in the light of onomastics. The principal aim of this onomastic survey is to determine the westernmost boundary of Permic hydronyms. A secondary aim is to distinguish different ancient Permian groups from one another, since the hydronyms suggest that there have possibly been four different kinds of Permian groups during the Middle Ages: Udmurt, Komi, northwestern (?Komi dialect) and Meščera. To some extent, folklore, historical data and the history of different linguistic contacts have also been taken into account. The onomastic exploration has concentrated on the most usual Permic stems and Udmurt formants. In addition, the generic form -jug $(a)$ has been examined.

1. Introduction

2. Methods and sources of research

3. Permic stems of hydronyms

3.1. Presentation of old

Permic stems

3.2. Some special questions

3.3. Discussion
4. Generics $-j u,-(j) u k$ and $-(j) u g$

5. Conclusions

Appendix

\section{Introduction}

The stimulus for this present article has been the critique of my article The Linguistic Background of the Ancient Meshchera Tribe and Principal Areas of Settlement (2009: 162-202), presented by such scholars as Ante Aikio (2012: 69) and even an unknown writer of Wikipedia $(<$ https://en.wikipedia.org/wiki/Volga_Finns $>)$. In the article, I suggest that the Meščëra tribe spoke a Permic language. I admit that the study was not thorough enough. However, one should remember that the article was accepted and recommended for publication by three referees.

The question of a Permic layer of hydronyms west of Udmurtia and the Komi Republic (in Russia) is much wider than merely determining the language spoken by the Meščëra tribe, who lived by the banks of the Middle and to some extent Lower Oka (Rahkonen 2009: 160-200). Permian 
cultural influence towards the west has been discussed and proved for a long time by many scholars. Archaeological evidence shows many cultural waves from east to west originating especially from the rivers Kama and Čepca. The most prominent has been the spread of the Anan'ino Culture [800-300 BC] (Chalikow 1992: 53-64; Patrushev 2000: 89-99). Later, the Pjanobor-Čeganda [300 BC-400 AD] and Lomovatova Cultures [400-900 AD] brought new cultural waves over western territories from the Kama and Vyatka catchment areas (ibid. 2000: 162-171).

I am aware that archaeological material culture does not necessarily unambiguously reflect the ethnic or linguistic backgrounds of the people who manufactured and used the ancient objects found by archaeologists (see Rahkonen 2013: 33-37 and attached literature). However, cultural impacts may offer good opportunities to provide a hint at migrations, at least to some degree, and certainly at commercial contacts between different ethnic populations. Archaeological finds alone can seldom independently provide fully reliable proof of migrations, but when they are connected with corresponding toponyms - especially hydronyms - or historical literary sources, the evidence becomes much stronger.

Some toponymists, such as A. K. Matveev (1965; 1999), L. N. Žerebcov (1982: 26-40), N. D. Kabinina (2011) and A. Turkin (1971: 277-283) have noted ancient Permic toponymic layers in the Russian North west of the Komi Republic (see also Rjabinin 1997: 118, Map 33 based on Matveev 1964). Mihail Atamanov (2010: 127) has presented a map wherein the ancient Udmurt population (dating back to the first centuries before and the first millennium after the common era) extends into the eastern boundaries of Vologda and Kostroma oblasts, the entire Kirov oblast, most of Marij El, the northern parts of Čuvassia and the Kazan district in Tatarstan. Voronceva and Galkin (TRM 2002) have presented several etymologies of Permic origin in Marij El (the Republic of Mari in Russia) as well. Many of these have been criticized by O. V. Smirnov (2013). However, he also presents a Permic background for several toponyms in the Kirov oblast and Marij El (see Smirnov 2014: 11). Arja Ahlqvist (2001a: 240) has collected folk stories from the basin of the river Unža in Kostroma oblast. For instance, she has found a song that mentions Votyaks who lived in earlier times in the Unža region. ${ }^{1}$

According to many of the above-mentioned scholars, both archaeological data and toponyms suggest that in earlier times, the Permian population lived considerably further into the west than it does today. The important question is: Where is the westernmost boundary of Permic 
hydronyms? Does this boundary cover, for instance, the territory of the Anan'ino Culture, which spread westwards from the Lower Kama area (see Chalikow 1992: 58-59; Patrushev 2000: 90, Fig. 31)? In the following, I endeavour to struggle with this problem.

The structure of the present article is as follows. The methods and the sources of the study are presented in section 2. In section 3, I introduce 29 common Permic stems of hydronyms and 19 common Udmurt formants, as well as my explanations and interpretations thereof with comments. The aim is to introduce an overall picture of the western spread of Permic hydronyms in general and especially of the possible Permic layer of hydronyms in the Oka catchment area. In section 4, the usual Permic generic $-j u,-j u k, j u g(a)$ 'river' is discussed. The aim has been to study particularly the hydronyms with the generic -jug(a) in the area located in the western parts of Kirov and the eastern parts of the Vologda and Kostroma oblasts. The specialized target of this part of the research work is the reason this topic is presented in a separate section. Finally, in section 5, I present the summary.

The scientific transliteration of Cyrillic is used with some exceptions, i. e. when presenting widely known names of cities or rivers, such as Moscow, Yaroslavl, Arkhangelsk, Sukhona, Vyatka and Ryazan, or scientifically established expressions of the ethnoses 'Votyak' and 'Merya'.

\section{Methods and sources of research}

I have chosen to study hydronyms because they remain unchanged better than other toponyms. It is not always easy to point out which hydronyms are Permic. A hydronym may look exactly like a real Permic name, but still it may be derived from Russian, another Finno-Ugric language, or even from some unknown Paleo-European language. Where possible, I have tried, in the first place, to select names which have a Permic or at least a Finno-Ugric formant. ${ }^{2}$ This could be called a structural method, and this type of method is often used, by e. g. Matveev (2001) and Mullonen (2002). In some cases it regrettably has not been possible, especially if a hydronym consists only of the stem of the name.

Further, I have tried to ensure that there are no suitable Russian or non-Permic Finno-Ugric words behind the selected stems of hydronyms. I would like to emphasize that if someone wishes to criticize my solutions to the linguistic origin of the hydronyms, he or she should ask: If the back- 
ground of a hydronym is not Permic, what else could it be? If no other alternative can be found, the Permic origin should be considered most likely if it is lexically, phonetically and structurally possible and the motif of naming is reasonable. This could be called an exclusive method. Sometimes it is possible that both a good Russian and a Permic etymological alternative exist. For instance, hydronyms with the stem vil- may be derived from Permic vil- 'upper' (through a Russian adaptation) or Russian вил- [vil-] 'fork'. In such an occasion, I have approved only those hydronyms which have a Finno-Ugrian formant. Often it is also possible to check whether the geographical position of the object is reasonable grounds for it being called an 'upper' river or lake.

One may ask why I suppose, for instance, that $\operatorname{toj}(\mathrm{ma})$ hydronyms are Permic. Why not Meryan, as this type of hydronym also occurs in the area which is considered to be Meryan (Tojmiga GBO228; Tojmiga AVLO73A1, Tojmina AJO66A2)? A very important principle is to analyse the distributions of hydronyms. In the Permian area, there is a large river called Tojma, a tributary, flowing mostly parallel to the Kama. Further, the river Tojme $n k a<{ }^{*}$ Tojma is a tributary of the Vyatka. In the Komi area, a hydronym Tojma is found as well. The rivers Verh. and Niž. Tojma flow close to Komi in the catchment area of the river Dvina (north). In the areas of the Lower Kama, Vyatka and the Republic of Komi there is no considerable amount of names which could have connections with the Meryan type of hydronyms. In the Meryan area, however, there are plenty of Permic-type names (Map 1). Thus, the conclusion is that the origin of the name Tojma is most probably Permic - not Meryan - especially because of the possible Permic etymological and phonetic characteristics of the name (see hydronym number 24 below).

Every language has its own typical vocabulary and structure for naming geographical sites. Firstly, I have collected 29 common stems of macrohydronyms based on Permic languages occurring both in the Republic of Udmurtia and in Komi, where Permic languages are still widely spoken. It is known from historical sources that these territories have been populated by people who have spoken Permic languages for a long time - practically at least since the oldest available historical literary sources, but most probably for a much longer time (e.g. Atamanov 2010: 23-24). Secondly, I have examined Permic formants, especially Udmurt ones, compared with those of the Oka catchment area, as well as the distribution of the generic $-j u$, -juk, -jug(a) 'river'. 
In the following, I present 29 common stems and 19 Udmurt formants. The dictionaries Краткий этимологический словарь коми языка [LG] (Lytkin-Guljaev 1970), Udmurttilais-suomalainen sanakirja (MaksimovDanilov-Saarinen 20о8) and Удмуртская ономастика (Atamanov 1988), as well as the etymological list from Die Rekonstruktion der permischen Grundsprache [Cs] (Csúcs 2005: 320-400) are utilized here.

'glade, meadow'

'little'

'deep point in a river'

'stone, rock'

'meadow, grass'

'meadow, grass' [LG]

or 'broad, massive'

'pine forest'

'head, upper course'

'town, fortress'

'hare'

'log'

'woodpecker' or 'open place'

'granary, storehouse'

'Komi'

or 'deep water'

'long'

'bird cherry (tree)'

'deep'
Ko. $a \hat{z}$ [Cs] 'glade, meadow'; Udm. $a z ́$ id. < PPerm. ${ }^{\star} a \hat{z}$ id. [Cs]

Ko. ićét [Cs] 'little’; Udm. ić́i id. < PPerm. *ić 'little’ [LG], *iće [Cs]

Ko. jir, ir 'deep point in a river' < Old Komi ${ }^{*} j i r$; Udm. jer $[\mathrm{Cs}]<$ PPerm. ${ }^{*}$ jir $[\mathrm{Cs}]$

Ko. $i z$ 'stone, rock'; Udm. id. < PPerm. ${ }^{*} i z$ - id. [LG], $*_{i z(i)}[\mathrm{Cs}]$.

Ko. eža, Ko.Dial. iža 'meadow'; Udm. ožo < PPerm. *eža

Ko. viź 'meadow'; Udm. voź id. < PPerm. *veź id. [Cs]

Ko. eža 'broad, massive' < PPerm. eñ̆ or ě̌̆ id. [LG]

Ko. jag 'pine forest'; Udm. id. < PPerm. id. [LG/Cs]

Ko. jur 'head, upper course'; Udm. jir id. < PPerm. *jur [LG/Cs]

Ko. kar 'town, fortress, house, bird's nest'; Udm. id. < PPerm. *kar id. [LG/Cs]

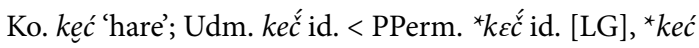
[Cs]

Ko. ker; Udm. id. < PPerm. ${ }^{\star}$ ker 'log' [LG]

Ko. kir [Cs] 'woodpecker'; Udm. kir or 'woodpecker' < PPerm. *kir [Cs]

Udm. kir 'steep (bank)', 'open place' [LG]

Ko. kum 'farmer's storehouse' [LG]

Udm. viži-kum, sara-kum 'Komi' < ? PPerm. ${ }^{\star} k s m i$ 'man' [Cs]

Ko. kuma|va 'deep water', in which $v a$ 'water' [LG]

Ko. kuź 'long'; Udm. id. < PPerm. ${ }^{\star} k u z ́$ id. [LG/Cs]

Ko. lém 'bird cherry'; Udm. id. < PPerm. * lóm [LG], *lóm [Cs] id.

Udm. mur 'deep' [LG] 
'nose, beak, cape'

'marsh, bog'

'(row)boat'

'black'

'rusty, dark'

'spring (of water)'

'horn, watershed'

'fire, burned area in forest'

'isthmus, neck of land’

'night, north'

'lower'

'big'

'upper'

'branch, tributary'
Ko. nir 'nose, beak, ? cape (in topon.)'; Udm. id. < PPerm. ${ }^{*}$ nür [LG], ${ }^{\star}$ nir id. [Cs] id.

Ko. ńur 'marsh, bog'; Udm. id. < PPerm. ${ }^{*}$ n̈̈rr [LG], ${ }^{\star}$ '́ur [Cs] id.

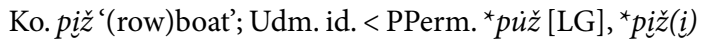
[Cs] id.

Ko. śed 'black'; Udm. id. < PPerm. * sód [LG], *'ód [Cs] id.

Ko. sim 'rusty, dark' < PPerm. ${ }^{*} \operatorname{sim}(V)$

Ko. śin 'spring'; Udm. ošmes-śin '(eye of) spring' < PPerm. * śinm- [LG]

Ko. śur 'horn', -śur 'watershed'; Udm. śur 'horn', śures 'way, pathway', śur-li 'spine' < PPerm. śur 'horn' [LG/Cs] Ko. tiv : till- 'fire', tila 'slash-and-burn area'; Udm. til ' 'fire', tilo '(small) leaf-tree forest (growing after slash-andburn cultivation)' < PPerm. ${ }^{*} t \dot{u} l$ 'fire' [LG], ${ }^{\star}$ tilla 'slashand-burn area' [Cs]

in Komi and Udmurt hydronyms ${ }^{\star}$ tojma; Ko. tuj 'pathway, track, road'< PPerm. ${ }^{*} t \ddot{8 j}<$ ? ${ }^{*}$ tej or ${ }^{*}{ }^{t}$ oj $<{ }^{*}$ taj-, Udm. hydronym Tujmi $\sim$ [official] Tojma $<{ }^{*}$ tojma $<$ ? Finno-Permic ${ }^{\star}$ tajma [track + suff. - $\left.m a\right]$ or $<{ }^{*}$ tajpa'bend'; cf. Fi. taipale 'track over an isthmus'

Ko. voj 'night, north'; Udm. $u j$ id. < PPerm. ${ }^{*}{ }^{*} j[\mathrm{LG}],{ }^{\star} o j$ [Cs]

Ko. $u v$ - : ul- 'lower'; Udm. $u l$ - id. < PPerm. ${ }^{*} u l$ - id. [LG/ Cs]

Ko. una 'much'; Udm. uno id. < PPerm. * ${ }^{*} n a[\mathrm{LG}],{ }^{*}$ una [Cs] id.

Ko. viv- : vil- 'upper'; Udm. vil- 'upper' < PPerm. ${ }^{*}$ vìl [LG], ${ }^{*}$ vil [Cs]

Ko. vož 'branch, tributary' $<$ PPerm. ${ }^{*} v \jmath z ̌[C s]<{ }^{*}$ voša id.

Abbreviations: Ko. $=$ Komi language, Udm. $=$ Udmurt language, PPerm. $=$ Proto-Permic 
Many motifs of the stems mentioned above correspond with the most common Finnish and Saami stems in Finland (Kiviniemi 1990: 184-185; Saarikivi 2004: 186-187). It is obvious that if in a territory under investigation only very few of most common stems are found, this casts uncertainty upon the interpretation. But if most or several of these stems are found, the result is much more reliable. It is noteworthy that my solutions for the original meanings of the hydronyms which I have presented independently correspond rather well with the interpretations of Afanas'ev (1996).

There are certain formants in Udmurt hydronyms that are widely found in the Oka territory as well. The most common Udmurt formants according to the definition of Atamanov (1988: 60-61, 74-81) are as follows:

-mes meś $\sim$ mas $\sim$ mos - ? 'spring' (Atamanov 1988: 60); -oj -uj -aj - ? 'brook' (ibid. 1988: 61); - $z i$ (in official names $-3 u,-3 я$ ) - unclear (ibid. 1988: 76); -ći (in official names $-\imath u,-u, a)$ - unclear (ibid.); -si - unclear (ibid.); -ma -mo - unclear (ibid.); -man - 'wet' (ibid. 1988: 77); -mak - unclear (ibid.); - miž -miš - unclear, possibly < Udm. dial. miž 'unclean' (ibid. ); -iž - $i z ̌ z$ - possibly not derived from any independent word (ibid. 1988: 78); -inga -inga - unclear (ibid.); -ićc - -ićc - unclear (ibid.); -let $\sim$-let' - unclear (ibid.); -im -um - ? < Mans. formant -um. Note the river Um in the catchment area of the Čepca (ibid. 1988: 79); -ur - -ir - ?< Mans. appellative ur 'back, shoulder, neck' (ibid. 1988: 8o); -pa -ba - unclear (ibid.); -baš - in Turkic languages $b a s ̌$ 'head, upper part, source of river' (ibid. 1988: 80); -ganda $\sim$-ginda $-<$ Old Hindi ${ }^{\star} k a n t x a$ 'town' (ibid.); - tan $\sim-$ dan - IE ${ }^{\star}$ danu 'river' (ibid.).

It is noteworthy that the linguistic origin of a considerable amount of the Udmurt formants is unclear. Even many of those which Atamanov explained are not certain, and some of them are completely unconvincing. This hints at their early origin. Most of these formants are not found in the hydronyms of the Komi Republic. Some of the Udmurt formants might have correspondences in other Finno-Ugric languages: - oj $\sim$ Finnic -oja (NA; Matveev 2001: 256-261); -zi, -si Finnic -si, later -nen : -sen, Meryan -ś/-z(a) (NA/toponyms of Ingria; Ahlqvist 2001b: 443-444); -ći Northern Russian substrate $-\check{c} \sim$ Proto-Finnic diminutive ${ }^{*}-\check{c} \check{c} u$ (Saarikivi 2006: 32); - $m a \sim-m a \sim$ Finnic, Meryan - $m(V)$ (NA; Saarikivi 2006: 31; Ahlqvist 2001b: 440); -inga -inga -nga -n'ga in the Russian North (Matveev 2001: 261-275); - ga|nda -gi|nda Finnic -nto, Meryan -nda (Ahlqvist 2001b: 439-440), in which the element -ga-/-gi- may be derived from the word *jug(a/i) 'river'. 
In the Komi onomasticon, pure formants are relatively rare. Such pure formants as e. g. - la, $-r a,-e b$, -im and -in are found (Afanas'ev 1996). Usually generics are used. ${ }^{3}$ Such generics can be found as: - va 'water', -ju 'river', -vož 'tributary', -jol' 'brook', -šor 'brook', -čer/-ser 'tributary', -il 'upper source', -ti 'lake', -vad 'lake (in forest)', -kur'ja 'bay in river', -bežz 'tail, end', -pom 'end', -vom 'mouth', and -vis 'connecting river between a river and a lake' (ibid. 1996). Many of these, in turn, are not found in the Udmurt onomasticon. This proves that independent development has taken place after the split of these languages from the proto-language, especially in Komi. The transparency of the Komi hydronyms compared with those of Udmurtia gives proof of their later age. The amount of generics in the Komi lexicon is higher than in Udmurtia. This is usual among any populations which have a close relation to nature, for example for fishermen-hunters compared with farmers, and especially with urban populations. This is notable in Komi and even to a much greater extent in the Saami, Hanti and Mansi lexicon.

It should be understood that specifics usually survive for longer than generics in substrate names. This is because of the very usual occurrence of semi-calques in bilingual situations. This phenomenon is well attested, for instance, in modern Russian Karelia and Veps territories (Mullonen 2002: 105-106; Rahkonen 2010: 66-67). In the Oka catchment area, such Udmurt formants have been productive as -mes/-mas, -ur, -im, - $p a /-b a$, -ić, -man, ${ }^{*}-s i>-s a,{ }^{*}-\check{c} i>\check{c} a,-m a$ and $-u j$.

The hydronyms presented below are collected from the regional maps AUR, ARK, AKiO, NN, AKO and AVO and from the onomastic dictionaries GBO, Топонимия республики Коми (Afanas'ev 1996) and TRM (see References). The research area consists of the Republics of Udmurtia, Komi and Marij El; the oblasts of Kirov, Kostroma and Vologda; and the catchment area of the river Oka. Possible Permic hydronyms in the Arkhangel, Yaroslavl, Ivanov and Vladimir oblasts are discussed occasionally. Unfortunately I did not have the possibility to use the archive of the Urals State University in Ekaterinburg or L. E. Kirillova's Микротопонимия бассейна Кильмези (2002). However, for our purposes, the sources that have been utilized provide a sufficient overall picture.

In the following, the Russian dictionary used has been Dal"s Толковой словарьживого велико-русского языка 1880-82 and the Mordvin dictionary Paasonen's Mordwinisches Wörterbuch 1990-96. Additional sources are presented separately. 


\section{Permic stems of hydronyms}

The distribution of the most common Permic stems of hydronyms is presented in Map 1. The aim has been to clarify the western boundary of these names. For this reason, the picture is limited in the east and south. Hydronyms that occur in Perm oblast and in the Republics of Tatarstan and Chuvashia are not investigated, although it is clear that a huge amount of Permic hydronyms exists in these territories.

In the distribution map, the hydronyms are marked with certain signs (black circles). Usually in the Permic word for 'black' Ko. and Udm. śed the vowel $e$ is substituted in Russian with $e>\mathrm{Ru}$. Adapt. ced- [sed] (see hydronym 19 in the list below). However, in the northern Russian lakeland, stems with $\operatorname{cod}$ - [sod-] are found (ibid.). One may suspect that the latter one reflects the Proto-Permic * śód (Lytkin-Guljaev 1970 s. v. cböd). Therefore, these hydronyms are marked on the map with $\mathbf{S}$. It seems obvious that stems with tojm- or toj 'neck of land' + a formant reflect an older stratum of Permic. The modern Udmurt version of the official name Tojma is Tujmi (Atamanov 1988: 80). Because it is possible that this stem is also very old, it is marked separately with T. The Proto-Permic word $\star_{0} 0$ ' north, night' (Lytkin-Guljaev 1970 s. v. Boŭ) occurs in Komi > voj and in Udmurt $>u j$. Occurrences of these forms are marked separately with $\mathbf{V}$ and $\mathbf{U}$ in order to see from which of them the more western forms of the stems originate. Unža hydronyms are marked separately with black and white squares (see Map 1), because it is not known for sure whether the hydronym consists of two components, un 'big' + -ža formant (as suggested by Ahlqvist 2001a: 228), or if there has once existed an appellative ${ }^{\star} u n z \check{z} a$ or ${ }^{\star} u n \check{a} a$ with an unknown meaning and in an unknown language. ${ }^{5}$ Personally, I tend to accept the explanation presented by Ahlqvist.

Some of the solutions concerning the original meaning of the stems presented below are not fully certain. A major problem arises from the characteristics of the Permic languages. In Permic languages, words are usually shortened, consisting often of only one syllable with such types as $\mathrm{CV}, \mathrm{VC}$, CVC and VCC. The type with two syllables, CVCV, is rarer (see Bartens 2000: 66). Among the 29 stems studied in the present work, words of the type VC are: $a z_{-}, i r-, i z-, u j-$ and $u l-; \mathrm{VCV}$ are ići-, eliža- and uno-; CVC are jag-, jur-, kar-, ké̌́-, ker-, kir-, kum-, kuź-, lém-, mur-, nir-, ńur-, piž-, śéd-, sim-, śin-, sur-, vil- and vož-; and the one CVCV example is tillo-. In addition, there is the word tojma, which is here suggested to have been a Proto-Permic word. 


\section{I. Presentation of old Permic stems}

In the following, after the presented Komi hydronyms, I have added the meanings of the words from which the stems are derived as presented by A.P. Afanas'ev (1996) with Af. and the page number. Etymological suggestions are adopted from Lytkin-Guljaev (1970) [LG] and/or Csúcs (2005) [Cs]. Variation occurring in Komi is presented according to Afanas'ev (1996), but unfortunately several of the names presented here occurring on the maps are not found in his rather short list of toponyms.

\section{1. $A z$ - 'glade, meadow'}

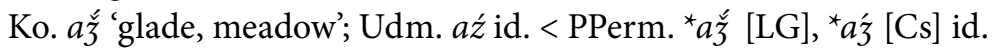

UdmuRTia: Az|evka (AUR42B2), a small tributary of the Kama, slightly in Tatarstan, close to Krasnyj Bor.

KomI: $A d z^{\prime}|v a \sim A d z| v a(\mathrm{ARK} 17 \mathrm{G} 6)$, a large tributary of the Usa in the catchment area of the Pečora in northern Komi.

- Af. (20) 'meadow'.

KIrov: $A z \mid v a z ̌\left(\mathrm{AKiO}_{33} \mathrm{~V}_{3}\right)$, a small tributary of the Sjusjum in the catchment area of the Pižma in the western part of the oblast.

Vologda: Azlen'ga (AVO19V4), a small tributary of the Pežma in the catchment area of the Vaga south of Vel'sk.

MARIJ El: Az|eyer (TRM25), a tributary of the Kazanka.

NižniJ-Novgorod: Aza Buturlino \| Aza|nka Bol. Boldino. ${ }^{6}$

Oка: $A z a \mathrm{GBO} 249$, a middle-sized tributary of the lower Cna close to the estuary of the Mokša.

- No possible Russian, Mari or Mordvin origins are found.

\section{Ič- 'little'}

Ko. ičet 'little'; Udm. ič́i id. < PPerm. *ić- [LG], *iće [Cs] 'little'

UdMURTIA: ?? Itč|ej|ka (AUR26B2), a middle-sized tributary in the catchment area of the Vala in Central Udmurtia.

KoмI: Ičet|vad oz. (ARK95V4), a small lake in the upper course of the Malaja Vizinga in the Sysola catchment area close to Syktyvkar \|I Ičet'|jol' (ARK6oA4), a small tributary of the Lem'ju in Pečora catchment area in Central Komi || Ičet'|ju (ARK1ooB1), a small tributary of the Piv"ju in the Vyčegda catchment area. - Af. (69) 'little'. 
Kostroma: $I \check{c} \mid e \check{z}\left(\mathrm{AKO}_{35} \mathrm{~A} 1\right)$, a small tributary in the upper course of the Unža.

Vologda: Ič|ma (AVO49B4), a small tributary of the Jug in the easternmost corner of Vologda oblast.

ОкА: Iča (GBO94), close to Moscow \|I Ića|l|ka (GBO264), close to Murom \| Iče|nka (GBO133), close to Murom || Iče $\mid \check{z} a\left(\mathrm{ARO}_{40 \mathrm{O} 1}\right)$, a small upper course of the Jermiš in the Lower Mokša || Ič|ka (GBO1o8), close to Moscow || Ičlerhi oz. (GBO232), close to the estuary of the Mokša.

- No possible Russian or Mordvin etymologies are found. The stems of names in the Oka catchment area often seem to reflect Proto-Permic ${ }^{*} i c e$ (Csúcs 2005), with the preserved final vowel $e$.

\section{Ir- 'deep point in river'}

Ko jir, ir 'deep point in a river' < Old Komi ${ }^{*} j$ jir ; Udmurt jer [Cs] < ? PPerm. *jir [Cs]

UdmuRtia: Ir $|e j| k a(A U R 26 \mathrm{~B} 2$ ), a small tributary of the Uva in the Vala catchment area in Central Udmurtia \|Ir|in'ga (AUR29B4), a small tributary of the Votka in the Siva catchment area in eastern Udmurtia \| Ir $\mid$ im $\mid k a(A U R 21 \mathrm{~A} 5)$, a small tributary of the Čepca.

KomI: $\operatorname{Ir} \mid v o z ̌ z\left(\mathrm{ARK}_{77} \mathrm{~B}_{4}\right)$, a small upper course of the Kyltovka in the Vym' catchment area in Central Komi \|| Ira|jol' (ARK4oG3), a small upper course of the Čikšina in the Pečora catchment area in northern Komi || Jir (ARK106G1), an upper branch of the Sysola in southern Komi. Afanas'ev (1996): Ir|va Jir|va Udorskij rajon, Ir"|ju Jir"|ju Knjažpogostskij rajon Jira|jol' Sosnogorskij rajon - Af. (69) 'deep point in a river'

KIrov: Ire|ka (AKiO64A3), a middle-sized tributary of the Uržumka in south-eastern Kirov oblast (mostly flowing in Marij El) \|Ire|kša (AKiO62B1), Ir $\mid k a\left(\mathrm{AKiO}_{55} \mathrm{~A} 4\right)$, a small upper course of the Suda in the Pižma catchment area in southern Kirov oblast || Irị $\mid k s ̌\left(\mathrm{AKiO}_{53} \mathrm{~V}_{4}\right)$, a small upper course of Mamokša in the Bol. Kokšaga catchment area in south-western Kirov oblast || Ir|juk (AKiO66V1), a small tributary of the Šošma in the Vyatka catchment area in south-eastern Kirov oblast. MARIJ EL: Ire|kša (TRM93), a tributary of the Bol. Kokšaga.

NižniJ-Novgorod: Ire|st' Počinki || Ir|ža Ardatov.

ОкА: Ira (GBO231) close to the estuary of the Mokša \|Ir $\mid z ̌ a\left(\mathrm{GBO}_{261}\right)$ in the Lower Mokša || Ir|mes Ir|mis $\left(\mathrm{GBO}_{216}\right)$ in the Nerl' area in the Kljaz'ma catchment area. 
- In Russian, no possible original source is found. Mordvin ir 'hailstone' is unsuitable as a motif for naming. In the Oka catchment area, an Udmurt formant -mes is found, as in Ir|mes (GBO216). It seems that in some cases, the second vowel $e$ has survived $<{ }^{*}$ jir $(e)$.

\section{Iz-'stone, rock'}

'stone, rock' Ko. iz 'stone, rock'; Udm. id. < PPerm. ${ }^{\star} i z-[\mathrm{LG}],{ }^{\star} i z(i)[\mathrm{Cs}]$ id.

UDMURTIA: $I z|e j| k a$ (AUR26B1), a middle-sized upper course of the Uva in the Vala catchment area in Central Udmurtia \|Izo|šur (AUR1oV1), a middle-sized tributary of the Pyzep in the Čepca catchment area in the vicinity of Glazov \|Izo|šur (AUR16B1), an upper course of the Lyp in the Čepca catchment area in north-eastern Udmurtia.

KomI: Iz|šor (ARK28A5), a small river in the Urals slightly in Tjumen oblast || Iz"|jol'(ARK45V5), a small tributary of the Belaja Kedva in Ižma catchment area in Central Komi close to Uhta $\| I z^{\prime \prime} \mid j o l l^{\prime}$ (ARK85A5), a small tributary of the Madža in the Vyčegda catchment area close to Syktyvkar. Afanas'ev (1996): Iz"ja|šor Prijužkij rajon, $I z^{\prime \prime} j a \mid j u$ Pečorskij rajon (2 rivers) - Af. (68) 'stone'.

ОкА: Iz|gor (GBO254) || Iz|ur|ka (GBO189) close to Ryazan.

- In Russian, no suitable etymological source is found. Mordvin iza|ms 'to harrow' is unlikely for a motif used in naming. In the Oka catchment area, an Udmurt formant -ur $(I z|u r| k a)$ is found. In the name $I z \mid$ gor, one finds the latter element gor $<{ }^{\star} k u r$ 'lake' (Rahkonen 2012: 30 and attached literature).

\section{5. $I \check{z}$ - 'meadow' or 'broad, massive'}

Ko. eža, Ko.Dial. iža 'meadow'; Udm. ožo < PPerm. * e्र̌̌a 'meadow, grass' [LG] Ko. ěza 'broad, massive' < PPerm. eñ̆ or ěž [LG] id.

UDMURTIA: Iž (AUR28B3), a massive tributary of the Kama in southern Udmurtia || I $\check{z}$; Bol. (AUR28B3), the western upper course of the Iž || I $\check{z}$; Mal. (AUR28A3), the eastern upper course of the Iž.

KомI: $I \check{z}|m a \sim I z| v a(\mathrm{ARK} 33 \mathrm{~V} 6)$, a large tributary of the Pečora in northern Komi. - Af. (67) 'meadow-'

KIROv: $I \check{z}\left(\mathrm{AKiO}_{45} \mathrm{~V}_{4}\right)$, a large tributary of the Pižma in the Vyatka catchment area in southern Kirov oblast

MARIJ EL: Iž|ovko|eyer Iž|ovka (TRM74), close to Joškar-Ola. 
NižNij-Novgorod: Ižma Voskresenskoe, a middle-sized tributary of the Vetluga.

ARKHANGEL: $I \check{z} \mid m a$, close to the city of Arkhangelsk.

ОкА: Iž|evskoe (GBO128) in the Meščëra area \|I Iž|ičlenka (GBO88) in the Kaluga-Serpuhov area

- The origin of the stem is unclear. On the one hand, the motif of PPerm. *e ̌̌a 'meadow' [LG] is suitable. On the other hand, some of these rivers are very large, and therefore the motif 'broad' PPerm. ${ }^{\star} e{ }^{\prime}{ }^{-}$[LG] seems more suitable. No possible Russian or Mordvin origins are found for these stems. In the Oka catchment area, an Udmurt formant -ič (Iž $|i c ̌| e n k a)$ is found.

\section{Jag-'pine forest'}

Ko. jag 'pine forest'; Udm. id. < PPerm. *jag [LG/Cs] id.

UdmuRTIA: Jaga (AUR39A5), in the headwaters of the Umjak, a large tributary of the Vyatka || Jag|vaj|ka (AUR23A4), an upper course of the Itinka and Ita in the catchment area of the Čepca in north-eastern Udmurtia \| Jago|šur (AUR1oV2), headwaters of the Čepca in northern Udmurtia \| Jago|šur (AUR14B1), a small tributary of the Junda in the catchment area of the Čepca in northern Udmurtia \| Jago|šur (AUR13 B5), a small river in the headwaters of the Sepyc-Parzi in the catchment area of the Čepca in northern Udmurtia \| Jago|šur (AUR13A4), a small tributary of the Ubyt' in the catchment area of the Čepca \| Jago|šur (AUR1oB1), a small river in the headwaters of the Sypec-Mučan in the Čepca catchment area \| Jago|šur (AUR14V1), a small tributary of the Kep in the Čepca catchment area in northern Udmurtia $\| J a g|u l| k a\left(A U R 28 V_{2}\right.$ ), a small tributary in the Iž catchment area in Iževsk $\| J a g|u l| k a\left(\mathrm{AUR}_{32} \mathrm{~V}_{1}\right)$, a small upper course of the Ljuga in Vyatka catchment area in south-western Udmurtia.

Kомг: Jaga (ARK107aB1), a small upper course in southern Komi || Jaga|jol' (ARK10oB2) a small upper course in the headwaters of the Vyčegda in southern Komi || Jag|vož (ARK72B2), a small upper course of the Post'Sed"ju in the Ižma catchment area in Central Komi \| Jag|ul (ARK95V4), a small tributary of the Malaja Vizinga in the Sysola catchment area in southern Komi || Jag'|jol' (ARK8oA1), a small tributary of the Nivšera in the Vyčegda catchment area in Central Komi \|Jag'ju (ARK85B5), a small tributary of the Madža in the Vyčegda catchment area close to Syktyvkar. - Af. (164) 'pine forest' 
Ока: Jago|ma (GBO218) close to the city of Ivanovo \|| Jagu|b|ovskoj (GBO219) close to the city of Ivanovo.

- The Udmurt formants -ma (Jago|ma) and - $b<^{*}$-ba (Jagu|b|ovskoj) are found in the Oka catchment area. In Russian, яга [jaga]; cf. баба яга [baba jaga] 'witch' is not very suitable as a motif for naming.

\section{Jur- 'headwaters, head'}

Ko. jur 'head, upper course’; Udm. jir id. < PPerm. ${ }^{\star}$ jur [LG/Cs] id.

UDMURTIA: Jur $|a s ̌| k a\left(\mathrm{AUR}_{39} \mathrm{~V}_{3}\right)$, a middle-sized tributary of the Umjak in the Vyatka catchment area partly in Tatarstan $\| J u r \mid a s ̌\left(A_{3} R_{39} 4\right)$, the upper course of the Juraška (see above) \| Jur|aš|ka (AUR4oV1), a middle-size tributary of the Tojma partly in Tatarstan $\| J u r \mid k a$ (AUR8G2), a small upper course of the Sada-Lekma in the Čepca catchment area in north-western Udmurtia.

KoмI: Jur|om|ka Jurum (ARK76G2), a middle-sized tributary of the Vyčegda in Central Komi \| Jur|šor (ARK19B9), a small river in Vorkuta, north-eastern Komi. Jur'ja (id. Kirov) - Af. (164) 'deep point in a river' or 'head'.

KIrov: ?? Jur'|ja (AKiO16G2).

Kostroma: Jur|ma|nga $\left(\mathrm{AKO}_{31} \mathrm{~B} 1\right)$, a large upper course of the Sundoba close to Čuhloma in north-western Kostroma oblast || Jur|man $\mid k a\left(\mathrm{AKO}_{57 \mathrm{~A} 2}\right)$, headwaters of the Viga close to Čuhloma in north-western Kostroma oblast \|Jur|m|ovka (AKO111 $\left.\mathrm{A}_{3}\right)$ headwaters of the Kus' in the Nel'šma catchment area in Central Kostroma oblast || Jur|ong|aš (AKO156A1), a large tributary of the Šuja in south-eastern Kostroma oblast \|Jur|ǐs $\left(\mathrm{AKO}_{171} \mathrm{~A}_{3}\right)$, a small tributary of the Nodoga in southern Kostroma oblast. VoloGDA: Jur|ma|nga (AVO63B6), a small tributary of the Leden'ga in the Sukhona catchment area in eastern Vologda oblast || Jur|ma|nga $\left(\mathrm{AVO}_{3} \mathrm{~V}_{4}\right)$, a small tributary of the Tolšma in the catchment area of the Sukhona || Jur|ma|n'ga (AVO41A5), a small tributary of the Kuloj in the Vaga catchment area $\| J u r|m e| n^{\prime} g a\left(\mathrm{AVO}_{4} 6 \mathrm{~B}_{2}\right)$, a middle-size tributary of the Sukhona in eastern Vologda oblast.

MARIJ EL: Jur|anga Jar|ang (TRM4Oo), a tributary of the Vetluga.

NižNiJ-Novgorod: Jur|ika (AKiO43 $\mathrm{A}_{3}$ ), a tributary of the Pižma.

Ока: Jur (GBO252) in the Lower Cna \|Jura (GBO195) close to Meščerskij Gorodec \| Jura (GBO270), close to the city of Murom. 
- The Russian dialectal form юpa, юрага [jura, juraga] e. g. 'churning' is not suitable for naming. A personal name Юрuц̌ [Jurij] may be the source of Jur'ja in Kirov oblast. However, if this name can be derived from the anthroponym it should be usual everywhere in Russia, but e.g. in the Oka catchment area, Kostroma, Vologda, Yaroslavl or Tver oblasts no Jur'ja rivers are found. The ending -ja might reflect Permic $-j u$ with the Russian influence $u>a$ as the feminine marker. Mordvin jur 'stump' is not a very probable element in naming. Both Voronceva-Galkin (TRM40o s. v. Юрченка) and Afanas'ev (1996 s. v. Юромка) derive this stem in some cases from jir 'deep'. At least the Jurma|nga rivers (AVO41 $\mathrm{A}_{5}, 63 \mathrm{~B} 6,63 \mathrm{~V}_{3}$, $\left.{ }_{82} \mathrm{~B}_{2}\right)$ and the river Jurme $n$ 'ga $\left(\mathrm{AVO}_{46} \mathrm{~B}_{2}\right)$ in Vologda oblast have no upper courses; i. e. they are the last ones in their water systems. The Jur $(m)$-rivers in Kostroma oblast $\left(\mathrm{AKO}_{31} \mathrm{~B}_{1}, 57 \mathrm{~A} 2,111 \mathrm{~A}_{3}\right)$ are also headwaters. Thus the origin of the stem jur 'upper course' is most suitable.

\section{Kar- 'fortified site, town, house'}

Ko. kar 'town, fortress, house, bird's nest'; Udm. id. < PPerm. ${ }^{\star} k a r$ [LG/Cs]

Udmurtia: Kara|vaj|ka (AUR2oB2), Karavajka-Ušnet is a tributary of the Kil'mez' in Central Udmurtia \| Kara|šur (AUR34B2), a very small river in southern Udmurtia close to the border with Tatarstan || Kar|šur (AUR1oG2), a small upper course of the Pysep in the Čepca catchment area.

KomI: ? Kara (ARK13G7), a large river in northern Komi. - Af. (70) Kara $<$ Nenets Hara.

KIrov: Kara ( $\mathrm{AKiO}_{39} \mathrm{~V}_{5}$ ), a narrow tributary of the Kosa in the catchment area of the Čepca.

Kostroma: Karljug (AKiO14V3), an upper course of the Vohma in the north-eastern corner of Kostroma oblast.

MARIJ EL: Kara|kša (TRMio8), a tributary of the Ošla \|Kara|mas|ka TRM108, a tributary of the Serdjažka.

- In Kostroma oblast and in Marij El, the Permic formants -jug (Kara|jug) and -mas (Kara|mas $\mid k a$ ) are found. The distribution strongly suggests a Permic origin for the stem. One should note that the word kar also has the meaning 'house' (Csúcs 2005 s.v. kar). At least in the Finnish onomasticon, stems that are based on buildings, i. e. aitta 'granary'; riihi 'kiln'; kota 'hut'; and maja 'cabin', but also linna 'fortified site', are usual (NA; Kivi- 
niemi 1990: 184-185). So-called hill forts were very usual among Udmurts during the Viking period (Atamanov 2010: 160) and already in the early Iron Age among Finno-Ugric tribes in the Lower Kama, Oka and Upper Volga area (e. g. Tret'jakov 1966: 145-156; Bartens 2000: 10). This proves that the meaning 'fortification' is very suitable. In the area where the Tatar language has been spoken, the word kara 'black' could be possible. Among the above-mentioned Udmurt stems it is not probable, because of the attached Udmurt generics -vaj 'brook' and -šur 'river'.

\section{Keč- 'hare'}

Ko. keč ‘hare’; Udm. keć id. < PPerm. ${ }^{\star} k \varepsilon c \dot{c}[\mathrm{LG}],{ }^{\star} k e c ́$ [Cs] id.

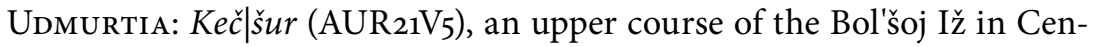
tral Udmurtia || Keč|evka (AUR35B4) a middle-sized tributary of the Iž in southern Udmurtia.

Komi: Kečlpel' (ARK19V7), a tributary of the Usa close to Vorkuta in northeastern Komi. - Af. (74) 'hare'.

Ока: Keč|ka (GBO169), close to Ryazan ||Keč|kura (GBO201), in the headwaters of the Kljaz'ma close to Moscow || Keč|uga GBO215 in the headwaters of the Nerl' [Kljaz'ma] || Keć (GBO237), in the Lower Mokša.

- No suitable Russian origin is found for this stem. In Mordvin, MdM kəčä 'gull' as a naming motif could be possible in the Oka catchment area. Mordvin keče kečä 'scoop' is also a rather usual motif for naming, but the formants do not refer to a Mordvinic origin. It is possible that the word ${ }^{\star} k e \check{c}(V)$ 'sun, day, circle' existed in Meryan or Muroma; cf. Mari keče Fi. $k e h \ddot{a}$ 'circle'. However, this is not a usual motif for naming. It is probable only if $k e \check{c}(V)$ would have had the meaning 'south'.

\section{Ker- ' $\log$ '}

Ko. ker ' $\log$ '; Udm. kor id. < PPerm. ${ }^{\star} k e r$ 'log' [LG]

UdmURTIA: Ker|njur (AUR14V1), an upper course of the Kep in the Čepca catchment area in northern Udmurtia.

KomI: Ker"ju (ARK5oB1), a small tributary of the Mezen' in western Komi. - Af. (73) 'log'.

KIrov: Kerlec (AKiO16G6), an upper course of the Černaja Holunica in the catchment area of the Vyatka in northern Kirov oblast \|Ker|z|ja 
(AKiO49G5), a large tributary of the Loban' in the catchment area of the Vyatka in eastern Kirov oblast || Ker|mež (AKiO45V4), a small tributary of the Pižanka in the catchment area of the Pižma Kostroma: Kera (AKO182A2), a middle-sized tributary of the Volga close to Kostroma || Ker|baš (AKO138A2), a tribitary of the Vetluga. Ока: Kera (GBO234) in the Upper Mokša $\|$ Ker|mis (GBO252) in the Lower Cna.

- In the Russian dialect of Ryazan, the word керь [ker'] 'village' is found (Dal' II s. v. керь). This word could be a substrate word of Permic origin < Proto-Permic ${ }^{\star} k e r{ }^{\prime} \log$ ' [LG], i. e. referring to houses made of logs; cf. Komi $k e r \mid k a$ 'hut, house' < ker 'log'. If so, this is strong evidence of a Permic substrate in the Ryazan area. In the Oka catchment area and in Kostroma oblast, the Udmurt formants -mis < ${ }^{*}$-mes $[\mathrm{Ker} \mid$ mis] and -baš $[$ Ker $\mid b a s ̌]$ are found.

\section{Kir- 'woodpecker', 'steep bank' or 'open place'}

Ko. kir 1. 'steep (bank)' 2. 'woodpecker'; Udm. kivr 'open place' or 'woodpecker'

UdmuRTIA: Kirr|baš $\mid k a\left(\mathrm{AUR}_{3} 8 \mathrm{~B} 1\right)$, an upper course of the Šija in the catchment area of the Vyatka, slightly in Tatarstan.

Komi: Kir"jol' (ARK98V1), an upper course of the Čed in the catchment area of the Lokčim-Vyčegda in southern Komi \|K Kirlju (AUR71V6), an upper course of the Nivšera in the catchment area of the VišeraVyčegda in Central Komi \| Kirljuga (ARK25G4), a small tributary of the Pečora in northern Komi. - Af. (85) 'slope'.

KIROv: Kir $|m i z z| k a\left(\mathrm{AKiO}_{3} 8 \mathrm{~B} 2\right)$, a tributary of the Bystrica in the catchment area of the Vyatka in Central Kirov oblast || Kirlpa (AKiO29B4), an upper course of the Belaja Holunica in the catchment area of the Vyatka in eastern Kirov oblast \|Kir $|c ̌ a| n k a\left(\mathrm{AKiO}_{48 \mathrm{~V} 2}\right)$, a small tributary of the Voja in the Vyatka in eastern Kirov oblast.

VoloGDA: ? kirr > kir, Kir|č|uga $\left(\mathrm{AVO}_{4} 6 \mathrm{~V}_{3}\right)$, a tributary of the Kičmen'ga in the catchment area of the Jug.

MARIJ El: Kar $\mid m \partial z ̌$ (TRM172), a tributary of the Laž in north-eastern Marij El.

OKA: ? kir > kir, Kir|ka (GBO176), in the catchment area of the Pronja \| Kir|man|skoj (GBO264), close to Murom \|Kir|č|ka (GBO176), in the catchment area of the Pronja. 
- Through Russian adaptation, the shift ${ }^{\star} k i r>k i r$ is possible; $c f$. the official name Vili|šur $<{ }^{*}$ Vili $\mid$ šur $(A U R 20 A 2)$ in Udmurtia. No suitable Russian origin is found for the stem. An Udmurt formant -man (Kir|man $\mid$ skoj< Kir $\mid$ man) and a possible formant $-\check{c}(K i r|\check{c}| k a)$ are found, possibly reflecting the original ${ }^{*}-\tilde{c} i$, in the Oka catchment area.

\section{Kum - '(farmer's) store house, granary' or 'deep water' or 'Komi'}

Ko. kum 'farmer's storehouse', kuma|va 'deep water'; Udm. viži-kum 'Komi' (Csucs 2005) < PPerm. *kum 'granary' [Cs]

UdmuRTiA: ? Kuma|za|nka (AUR38V2), a small tributary of the Vyatka slightly in Tatarstan.

Komi: Kuma (ARK101V3), a tributary of the Prupt in the catchment area of the Vyčegda in southern Komi. - Af. does not mention.

Kirov: Kume|na (AKiO $37 \mathrm{~V}_{5}$ ), Kumena, Bol. \& Mal. (AKiO $37 \mathrm{~B}-\mathrm{V}_{5}$ ), a middle-sized tributary of the Bystrica in the catchment area of the Vyatka Vologda: Kum|baš (AVO45B5), an upper course of the Kondas in the catchment area of the Uftjuga in north-eastern Vologda oblast II Kume|n'ga (AVO47 44$)$, an upper course of the Kičmen'ga in northeastern Vologda oblast.

MARIJ El: Kuma (TRM155), a tributary of the Juronga in the catchment area of the Vetluga || Kum|už (TRM155), a tributary of the Ilet' $\|$ Kum|až"jer (TRM156), a lake close to Jaramor village, in Morki rajon.

OкA: Kume|nka (GBO180) in the Pronja catchment area.

- No suitable Russian or Mordvinic origin is found for the stem. The formant -na (Kume|na) is mysterious; cf. Kumena, Kubena, Sukhona. One possibility is an old Russian shift ${ }^{\star} m>n$, especially because of the regular previous labials $b$ and $m$ e.g. in Kume $\left|n a ?<{ }^{\star} K u m e\right| m a$ and Kube $\mid n a<$ ${ }^{\star}$ Kube|ma.

\section{Kuź- 'long'}

Ko. kuź 'long'; Udm. id. < PPerm. ${ }^{\star} k u z ́$ id. [LG/Cs].

UdMURTIA: Kuzi (AUR11G3), a relatively long and narrow upper course of the Pyzep in the catchment area of the Čepca in north-eastern Udmurtia.

Koмr: Kuz' jol' (ARK106V1), an upper course of the Koj in the Sysola catchment area in southern Komi. - Af. (82) 'long'. 
KIrov: Kuzo|voš|ka (AKiO57G5), a tributary of the Uržumka in the catchment area of the Vyatka in southern Kirov oblast || Kuz|jug (AKiO15V6), a long tributary of the Moloma in northern Kirov oblast.

Kostroma: Kuz|jug (AKO43 $\left.\mathrm{B}_{2}\right)$, a long tributary of the Voč'-Vohma in the Vetluga catchment area in north-eastern Kostroma oblast.

Vologda: Kuz|en'ga (AVO21V5), headwaters of the Uftjuga-Kokšen'ga in the catchment area of the Vaga in northern Vologda oblast || Kuzi|ma $\left(\mathrm{AVO} 25 \mathrm{~V}_{5}\right)$ a small tributary of the Verhnjaja Jerga in the Sukhona catchment area in north-eastern Vologda oblast.

Jaroslavl: Kuza (AJO23 $\left.\mathrm{B}_{3}\right)$, a long tributary of the Obnora in the Kostroma catchment area in north-eastern Kostroma oblast.

ОкА: Kuz|ma (GBO253), in the Lower Cna || Kuzo|ma (GBO270), close to Murom || Kuzo|va (GBO105), close to Moscow.

- In Russian, there is an anthroponym Kuzbma $\sim$ Kozbma (Dal' II s. v. Kyзвмa). However, the "soft mark" $b$ does not occur in the hydronyms presented here. There are such hydronyms as e.g. Kuzbmin (GBO61, 157, 268) and Kuzbmiščevskoj (GBO163) which can certainly be derived from the above-mentioned anthroponym. Atamanov (1988: 60) has pointed that the original Udm. ${ }^{\star} k u z$ ' 'long' becomes $>K u z$ - in toponyms through a Russian adaptation. The Permic formants - $m a(K u z o \mid m a)$ and -va (Kuzo|va) 'water' are found in the Oka catchment area.

\section{Lem- 'bird cherry'}

Ko. l'em 'bird cherry’; Udm. id. < PPerm. *lóm id. [LG], *lóm [Cs]

UdmuRTIA: Lem (AUR16G2), a small tributary in the headwaters of the Čepca in north-eastern Udmurtia || Lema (AUR12A3), a large tributary of the Lekma in the Čepca catchment area in north-western Udmurtia || Lem|ka (AUR17V2), a small tributary of the Lumpun in the Vyatka catchment area in western Udmurtia.

KomI: Lem (ARK8oG1), an upper course of the Lym|va in the Vyčegda catchment area in Central Komi || Lem|va L'em|va (ARK27G6), a large tributary of the Usa in north-eastern Komi \| Lem"|ju L'em|ju (ARK6oA2), (ARK61B6), a large tributary of the Pečora in Central Komi \| $L e m^{\prime \prime}\left|j u \sim L^{\prime} e m\right| j u\left(\mathrm{ARK}{ }_{77} \mathrm{~B} 5\right)$, a middle-sized tributary of the Višera in the Vyčegda catchment area in Central Komi $\| L e m "\left|j u \sim L^{\prime} e m\right| j u\left(A R K 85 V_{4}\right)$, a large tributary of the Vyčegda close to Syktyvkar. - Af. (88) 'bird cherry' 
Kirov: Lema $\left(\mathrm{AKiO}_{39} \mathrm{~V}_{5}\right)$, an upper course of the Kosa in the Čepca catchment area in eastern Kirov oblast.

VologdA: ?? Lema (AVO12V3), a tributary of the Megra.

ARKHANGEL: Lema (ARK64G2), a tributary of the Dvina north of Kotlas. NižNiJ-Novgorod: Lem|ša Gorodec, a tributary of the Uzola in the Volga catchment area in western Nižnij-Novgorod oblast

Ока: Lemet' (GBO267), a tributary of the Tëša close to Ardatov.

- No suitable origin for the stem exists in Russian. The Mordvin word l'em 'soup' is very unlikely to be the source. In Russian adaptation, Permic $e$ is usually substituted with Russian $e$; cf. Perm. śed $\sim \mathrm{Ru}$. Adapt. ced 'black' (see below). Thus the Permic lem 'bird cherry' is the most probable origin in all cases presented here with the exception of Lema in Vologda oblast $\left(\mathrm{AVO}_{12} \mathrm{~V}_{3}\right)$, which can more probably be compared with Fi. and Ka. lemi 'marsh' > Ru. Dial. лема [lema] id. (SSA II s. v. lemi).

\section{Mur- 'deep'}

Udm. mur 'deep'

UdmuRTia: $M u r \mid a\left(A_{2}{ }_{2} A_{3}\right.$ ), a long tributary of the Loza in the Čepca catchment area in Central Udmurtia.

Komi: $M u r^{\prime} \mid j u$ (ARK67V6), a tributary of the Čub in the catchment area of the Vym' in western Komi. - Af. does not mention.

KIrov: Mur|is (AKiO18V2), an upper course of the Poryš in the catchment area of the Kama in north-eastern Kirov oblast || Mur|it|ka (AKiO55A4), an upper course of the Iž in the Pižma catchment area in southern Kirov oblast.

KostromA: Mur|ža (AKO411B1), an upper course of the Jug in the Sukhona catchment area in northern Kostroma oblast.

OKA: Mur GBO232, an upper course of the Tašenka in the Oka catchment area close to Kasimov Meščerskij Gorodec $\| M u r \mid k a\left(\mathrm{GBO}_{240}\right)$ in the Lower Mokša \| Mur|ka (ARO38A4) a small river in the estuary of the Mokša.

- In Russian dialect (Arkhangelsk), there is a word $м y p z$ denoting a certain grass (Dal' II s. v. мypz). This is a possible but here unlikely motif for naming. In Mordvin, there is a form mur 'needlework', but this is also a very unsuitable source. 


\section{Nir- 'nose, beak, cape'}

Ko. nir 'nose, beak'; Udm. id., 'cape' < PPerm. * nür [LG], *nir [Cs] id.

UdmURTIA: Niro|šur (AUR21V5), an upper course of the Iž in Central Udmurtia.

KomI: Nirlos (ARK39G5), a large tributary of the Sebys' in the Ižma catchment area in northern Komi. - Af. (115) Hıьpoc Höpac < Ko. neris 'river with sharp bends'.

KIROv: Nir ( $\left.\mathrm{AKiO}_{44} \mathrm{~V}_{3}\right)$, a narrow tributary of the Jaran' in the Pižma catchment area in western Kirov oblast.

Arkhangel: Nir| $z a$ an upper course of the Pokšen'ga in the Pinega catchment area $\|$ Nir $|z a| n^{\prime} g a$ a small river in the Kuloj (North) catchment area

Ока: Nir|sa (GBO238), in the Lower Mokša.

- In the Oka catchment area, a possible Udmurt formant $-s a$ is found, reflecting the original ${ }^{\star}-s i$. The shift ${ }^{*}-i>-a$ is caused by the Russian influence; i. e. the feminine marker $-a$ in the names of rivers.

\section{Njur- 'bog, marsh'}

Ko. ńur 'marsh, bog'; Udm. id. < PPerm. *n̈̈r [LG], *nur [Cs] id.

UdmuRtia: Nur|ta (AUR16B3), an upper course of the Čepca slightly in Perm oblast.

KomI: Nuŕ|ju (ARK93D4), a small tributary of the Luza in the south-western corner of Komi Rep. - Af. (116) 'marsh'.

Kirov: Nur|jug; Bol. \& Mal. (AKO96B3), a large tributary of the Paozer in the Vetluga catchment area in western Kirov oblast.

Kostroma: Nur|jug (AKO93A2), a large tributary of the Vetluga in eastern Kostroma oblast || Nur|jug (AVO67G7), a middle-sized upper course of the Vohma in the north-eastern corner of Kostroma oblast.

VologdA: Nurenga (AKO38B1), an upper course of the Unža in southeastern Vologda oblast.

- Obviously derived from Permic ńur 'bog, marsh'. 


\section{Piž- 'rowboat'}

Ko. piž '(row)boat'; Udm. id. < PPerm. ${ }^{\star} p \dot{u} z ̌$ [LG], ${ }^{\star} p i z ̌(i)$ id.

UdmuRTia: Piž|man $\mid k a\left(\mathrm{AUR}_{31} \mathrm{~B}_{3}\right)$, a long tributary of the Vyatka in southwestern Udmurtia || Piž́|ja (AUR18B1), an upper course of the Kirčma in the Kilmez' catchment area.

Komi: Piž (ARK65V5), an upper course of the Vaška in western Komi \| ? Pižma (ARK32B3). - Af. (129) Piž < 'boat', Pižma < Ko. pižma 'a plant with composite flower'

Kinov: Piž $\mid a$ \& Piža|nka (AKiO39A4-5) small tributaries of the Filippovka in Čepca catchment area in eastern Kirov oblast || ? Pižma (AKiO46V1), a large tributary of the Vyatka \| ? several hydronyms with Piž-: Piž oz., Piž, Pižanka (3), Pižan'ja, Piž|il, most of them are located in the Lower Vyatka.

VolOGDA: Piž|ug (AVO47G6), a large tributary of the Kičmen'ga in the Jug catchment area.

MARIJ El: TRM264-265: ? Pižaj vüd, a tributary of the Laž || ? Pižan (1), a tributary of the Ošla || (2) a tributary of the Petjalka || Pižan'ja, a tributary of the Rutka.

OKA: Piža $|v| k a<{ }^{*} P i z ̌ a \mid v a\left(\mathrm{GBO}_{236)}\right.$ in the Upper Mokša || Piž|evskoj (GBO205), in the Upper Kljaz'ma close to Moscow \|P Pž $\mid i k$ (GBO172), in the Pronja catchment area $\| P i z z \mid i k\left(\mathrm{GBO}_{233}\right)$ close to the estuary of the Mokša || Pižlovskoj (GBO216), in the catchment area of the Nerl' [Kljaz'ma].

- No good Russian etymology is found. In the Oka catchment area, a possible Permic formant $-v a<$ PPerm. ${ }^{*} v a$ 'water' $\left(P i z ̌ a|v| k a<{ }^{\star} P i z ̌ a \mid v a\right)$ is found. According to Atamanov (1988: 76) *piž > piž- '(row) boat' is possible in hydronyms (see hydronyms in Kirov oblast and in Marij El). This is possible and there are analogues; cf. Vili|šur in which ${ }^{\star} i>i$ as a result of Russian adaptation. Galkin (TRM s. v. Пuжаŭ в̈̈d) thinks that the origin of the stem is Komi pež > piž (PPerm. pež 'dirty, muddy'). Because of the frequency of this stem, Galkin's explanation is not very believable. Instead, the etymology based on PFP * pǚš $>$ ? Pre-Perm. ${ }^{\star} p i \check{z}(\ddot{a}) \sim{ }^{*} p i z ̌(\ddot{a})$ 'holy, boundary' is possible (see Saarikivi 2006: 53), even though the word is not found in the modern Permic languages. This motif for naming is very usual in Finnic hydronyms. Other, at least phonetically possible, but not very probable, alternatives could be ${ }^{\star} p u \check{c}(k i)>{ }^{*} p u \check{z}$ - [theoretic deriva- 
tion] 'hollow stem' or ${ }^{\star} p e c ̌ e ~>{ }^{\star} p \ddot{u} z ̌->U d m$. pužim 'pine'; cf. vocalization according to Bartens 2000: 61, PFP ${ }^{\star} k e s k i>$ PPerm. küsk > Udm. $k u s(k-)$ and $\operatorname{Ko} . k o s(k-)$.

\section{Sed- 'black'}

Ko. śéd 'black'; Udm. id. < PPerm. * śód [LG], *sód [Cs] id.

Udmurtia: Sed|mič|ka (AUR9B4), an upper course of the Vyatka close to Glazov, northern Udmurtia \| Sed|mur|ča (AUR25G3), a large tributary of the Vala in western Udmurtia.

KomI: Sed (ARK105A4), an upper course of the Bol. Vizinga in the Sysola catchment area $\|$ Sed $\mid k a \sim S$ éd $\mid k a(A R K 110 G 2)$, a small tributary of the Luza || Sed|mes Sed|mes (ARK39B6), a large tributary of the Sebys' in the Ižma catchment area || Sed"|jol' (ARK73B5), an upper course of the Vol' in the Vyčegda catchment area \| Sed"|jol' (ARK59B5), a tributary of the Ižma || Sed"|jol' (ARK89A4), an upper course of the Požeg in the Vyčegda catchment area || Sed"|ju Śed"|ju (ARK9oV2), an upper course of the Vyčegda \| Sed"ju (ARK59B5), a large tributary of the Ižma || Sed"ju (ARK98B3), an upper course of the Lokčim in the Vyčegda catchment area \| Sed"ju (ARK25V7), a small tributary of the Usa in the Pečora catchment area \| Sed"ju (ARK42V $)$, a small tributary of the Bol. Patok-Šuger in the catchment area of the Pečora \| Sed"|vož Śed'|vož (ARK72A2), headwaters of the Sed"ju [Ižma]. - Af. (135) 'black'.

VologdA: ? Sod|enga (AVO22A2), an upper course of the Vaga || ? Sodi|ma $\left(\mathrm{AVO}_{77} \mathrm{~V}_{4}\right)$, a tributary of the river Vologda $\|$ ? Sodi|ma (AVO59G4), a small tributary of the Pel'šma in the Sukhona catchment area $\|$ ? Sodo|š $\mid k a\left(\mathrm{AVO}_{35} \mathrm{~V} 5\right)$, an upper course of the Perešnaja close to the Lake Vože || ? Sodo|š|ka (AVO36B2), a tributary of the Uftjuga [Kubena] || ? Sodo|š|noe oz. (AVO35V5), a lake between lakes Beloe and Vože. Ока: Sed $k a\left(\mathrm{GBO}_{146}\right)$, close to Serpuhov $\|$ Sed|ma (GBO253), close to the estuary of the Cna.

- No suitable Russian origin for the stem is found. In Mordvin there are such words as śed 'coal', sed 'bridge'. These are not very suitable motifs for naming. The Sod stem in Vologda oblast in the vicinity of lake Kubena and by the river Sukhona could possibly be derived from PPerm. *sóod [LG]. 


\section{Sim- 'rusty'}

Udm. sini 'rust' [Cs], Ko. sim 'rusty, dark' < PPerm. ${ }^{*} \operatorname{sim}(V)$ [LG], ${ }^{*} \operatorname{sim}(i)$ [Cs] 'rust'

Udmurtia: Sima|šur (AUR9V5), a small tributary of the Pyzep in the catchment area of the Čepca in northern Udmurtia close to Glazov.

Komi: Simpva (ARK7oB2), a tributary of the Vis close to the Lake Sindor|skoe in the Vym' catchment area in Central Komi. - Af. does not mention.

Kostroma: Sima|t|ovo oz. ? < ${ }^{\star} \operatorname{Sima} \mid t i(\mathrm{AKO} 135 \mathrm{~B} 2)$, a lake by the Middle Unža in Central Kostroma oblast.

Vologda: Sima (AVO38V2), a large tributary of the Kubena.

OKA: Sima|nga (GBO196), close to the estuary of the Kljaz'ma.

- No suitable Russian origin for the stem is found. The Mordvin derivations of the word sime|ms 'drink' are not probable in the Oka catchment area. It seems that in Merya-Muroma language there was such a word as *sim 'black' (Ahlqvist 2001b: 457-458; Rahkonen 2009: 177). It is difficult to determine whether Simanga (GBO196) in the Oka catchment area should be derived from a Permic or Muroma origin.

\section{Sin- 'spring (of water)'}

Ko. śin 'spring'; Udm. ošmes-śin '(eye of) spring' < PPerm. *'sinm- [LG], “'sin (śinm) [Cs] 'eye'

UdmuRtia: Sine|pur|ka (AUR19B3), a small tributary of the Ut' in the Kil'mez' catchment area in Central Udmurtia \| Sin|jar|ka (AKiO69B5), a small tributary of the Ljuga in the Vyatka catchment area in the south-western corner of Udmurtia.

KomI: Sin|dor|skoe oz. (ARK7oV2), a large lake in Central Komi. - Af. (137) Sindorskoe ozero < ugr. seng|tor 'misty lake'.

Kostroma: $\operatorname{Sin}^{\prime} \mid g a$ (AKO163A1), a small river close to Kostroma

VolOGDA: Siń|d|juk (AKO19A2), a small upper course in the Jug catchment area.

Ока: Sina|bor'|ja (GBO226) || Sine|bor|ka (GBO226; AVLO58A1), a tributary of the Kljaz'ma close to Vladimir. 
- The names Sina|bor'|ja (GBO226) and Sine|bor|ka (GBO226) in the Oka-Kljaz'ma region have an obvious analogue Sinepur|ka (AUR19B3) in Udmurtia. Afanas'ev has derived Sindorskoe oz. from Ugric languages. I suppose that the first component should be interpreted as sin $<$ Ko. sin 'spring' and the second component dor has the meaning 'by' > i. e. 'lake close to spring(s)'; cf. Ko. va|dor lit. 'edge of water', i. e. 'shore' (Afanas'ev 1996: 191).

\section{Sjur- 'horn, watershed'}

Ko. śur 'horn', -śur 'watershed'; Udm. śur 'horn', śures 'way, pathway', śur-li 'spine' < PPerm. śur 'horn' [LG/Cs]

Udmurtia: Sur|zi; Verh. (AUR13V4), an upper course of the Lekma in the Čepca catchment area in northern Udmurtia \| Sur|ek (AUR24V3), a tributary of the Vala in the Kilmez' catchment area in western Udmurtia || Sur|zja (AUR22B3), a tributary of the Ita in the Čepca catchment area in eastern Udmurtia \|S Sur|zja (AUR13 $\left.\mathrm{G}_{5}\right)$, an upper course of the Salja-Loza in the Čepca catchment area in northern Udmurtia \| Suro|vaj (AUR25B5), a small upper course of the Kejšurka-Kakmož in the Kil'mez' catchment area in western Udmurtia \|Ś Suro|vaj(AUR2oV3), an upper course of the Čur in the Iž catchment area in Central Udmurtia || Śuro|mo|šur (AUR19V3), an small upper course of the Arlet' in the Kilmez' catchment area in western Udmurtia.

Komi: Sur|sa (ARK96B1), a tributary of the Sop' in the Sysola catchment area in southern Komi. - Af. does not mention.

Ока: Sur (GBO261), close to the estuary of the Mokša \| Sur|zero oz. $\left(\mathrm{ARO}_{73} \mathrm{~A} 1\right)$, a lake in the confluence of the Cna and Mokša.

- No suitable Russian origin for the stem is found. A Mordvin etymology $<$ śuro śura 'horn' is possible in the Oka catchment area.

\section{Til- 'fire, slash-and-burn area'}

Ko tiv : till- 'fire', tila 'slash-and-burn area'; Udm. til 'fire', tilo '(small) leaftree forest (growing after slash-and-burn cultivation)' < PPerm. 'tul 'fire' [LG], ${ }^{\star}$ tila 'slash-and-burn area' [Cs]

Udmurtia: Tilo|vaj|ka (AUR22A3), a tributary of the Ita in the Čepca catchment area in eastern Udmurtia \|Tilloj (AUR21B4), a long trib- 
utary of the Njaz'-Loza in the Čepca catchment area in Central Udmurtia || Tilloj|ka (AUR22B2), a long tributary of the Ita in the Čepca catchment area in eastern Udmurtia \| Tỉlo|šur (AUR15B3), an upper course of the Syga-Pyzep in the Čepca catchment area in north-eastern Udmurtia.

Komi: Tila (ARK105A5), an upper course of the Poinga in the Sysola catchment area in southern Komi || Tila|jol' (ARK68G3), a tributary of the Vym' in Central Komi \| Tillaj (ARK112B2), a large tributary of the Luza in the catchment area of the Jug in south-western Komi || Tila|ju (ARK96A1), a small tributary of the Sysola in Central Komi. - Af. (146) 'land after slash-and-burn cultivation'.

Oка: Tillka (GBO184), in the catchment area of the Pronja II Tillma (GBO130), in the catchment area of the Pra.

- The Russian origin < mыл [ $t$ il ] 'backside' might be possible in the Oka catchment area in the name Tillka GBO184. The Finno-Ugrian (Udmurt as well) formant - $m a$ occurs in the name Till ma GBO130.

\section{Tojma, Toj- '(track over) neck of land, isthmus'}

Ko. $t u j$ 'pathway, track, road' < PPerm. ${ }^{\star} t \ddot{8 j}[\mathrm{LG}]+$ formant $-m a$ or ${ }^{\star}$ tojma 'neck of land' $\sim$ Fi. taipale 'neck of land' < ${ }^{\star}$ taje $(p a-w)$ 'bend' (see SSA III s. v. taipua)

UdmurTia: Tojma (AUR4OA2), a large tributary of the Kama in southern Udmurtia || Tojma; Mal.(AUR4oA2) a tributary of the Tojma in southern Udmurtia.

Komi: Tojma (ARK49A5), by the Vaška in western Komi \| Tuj (ARK8oV2), an upper course of the Nivšera in the Vyčegda catchment area in Central Komi || Tojem Tojęm (ARK67A6), a tributary of the Požva in the Vym' catchment area. - Af. (144) < Veps. toina 'second, another'.

KIrov: Tojme|nka (AKiO68B3), a middle-sized tributary of the Vyatka in southern Kirov oblast.

Kostroma: Toj|ga (AKO78B3), a tributary of the Veksa [Galič] || Toje|hta $\left(\mathrm{AKO}_{135} \mathrm{~A}_{3}\right)$, a tributary of the Unža in the eastern Kostroma oblast.

Vologda: Tojme|n'ga (AVO19A4), an upper course of the Semžen'ga in the Vaga catchment area $\| T o j \mid c a\left(\mathrm{AVO}_{32} \mathrm{~V}_{1}\right)$, a tributary of the Megra west of the lake Beloe $\| T_{0 j} \mid a\left(\mathrm{AVO}_{3} 8 \mathrm{~V}_{1}\right)$, a tributary of the Kubena.

ArKHANGEL: Tojma; Verh. \& Niž. large tributaries of the middle Dvina. 
Ока: Tojmilga (GBO228), in the estuary of the Kljaz'ma || Tojmi|ga (AVLO73A1), a small tributary of the Kljaz'ma, south-west of the town of Vladimir.

- No suitable Russian origin of the stem is found. In the background possibly is the Proto-Permic word ${ }^{\star} t \ddot{8} j>$ Komi tuj 'road' (Lytkin-Guljaev 1970: 22) + suffix - ma. Lytkin-Guljaev have apparently assumed that the Komi word is related with the Finnic ${ }^{\star}$ tee $>$ Fi. tie 'road'. However, it should be considered whether the Tojma-hydronyms should be connected to the Finnish taiva-l, taipa-le 'track over neck of land' < ${ }^{\star}$ taje $(p a-w)$ (see SSA III s. v. taipua 'bend') originating from a lost Permic word ${ }^{\star}$ tojma id. Tojma hydronyms are regularly attested to be rivers or lakes which are located geographically in necks of land or being one of closely flowing parallel rivers. In that case, ${ }^{\star}$ Tojma $>\mathrm{Udm}$. tujmi (id. the official Tojma in Udmurtia) could be derived from the earlier $>$ PPerm. ${ }^{*}$ tujma $\left({ }^{*} a>\right.$ PPerm. ${ }^{*} u$ according to Sammallahti 1988: 530) or, in the light of hydronyms, more likely PPerm. ${ }^{\star}$ tojma (as constructed ${ }^{\star} a>$ PPerm. ${ }^{\star} O$ according to E. Itkonen [1954] and V. Lytkin [1970]; see Sammallahti 1988: 530). The toj hydronyms seem to me to represent an early Permic layer of names, possibly from the Early Proto-Permic era (cf. Anan'ino Culture 800-300 BC). Afanas'ev's (1996: 144) explanation of the Finnic origin of the river Tojem (see above) cannot be correct because of the wide eastern distribution of tojma hydronyms. It may reflect older ${ }^{\star}$ tojema $<{ }^{\star}$ tajepa, so that the second vowel has remained.

\section{Uj-, Voj- 'night, north'}

Ko. $v o j$ 'night, north'; Udm. $u j$ id. < PPerm. ${ }^{*}{ }_{0} j[\mathrm{LG}],{ }^{\star} o j[\mathrm{Cs}]$

Udmurtia: $U j$ (AUR21A5), a tributary of the Ita in the Čepca catchment area in Central Udmurtia $\| U j|v a j| k a\left(A U R 22 A_{3}\right)$, a tributary of the Ita in the Čepca catchment area in eastern Udmurtia \|Uj|vaj|ka (AUR2oV2), an upper course of the Uva in the Kil'mez' catchment area. KомI: Voj|vož (ARK24V1, 34A2, 71B6, 78V4, 44G3, 78 G3, 81V4, 88A2, 9oV3, $38 \mathrm{G} 1,39 \mathrm{~B} 6,53 \mathrm{~B} 6,91 \mathrm{G} 7,80 \mathrm{~A}_{3}, 77 \mathrm{G}_{5}, 25 \mathrm{D}_{7}, 41 \mathrm{~V}_{7}, 61 \mathrm{~A} 7,67 \mathrm{~B}_{4}, 89 \mathrm{~A}_{4}, 67 \mathrm{G}_{5}$, $\left.54 \mathrm{~V}_{1}, 14 \mathrm{~V}_{3}, 66 \mathrm{~V}_{3}\right)$. - Af. (44) 'northern'.

KIROv: Voj|čliha (AKiO17V4), an upper course of the Kobra close to the border of Komi. 
Kostroma: Voj|mas (AKO62B3), a tributary of the Upper Unža in northern Kostroma oblast.

Vologda: Voj|ga (AVO19G5), an upper course of the Kovda in the Vaga catchment area $\| V o j \mid d u s ̌\left(\mathrm{AVO}_{40} \mathrm{VV}_{1}\right)$, an upper course of the Šičenga in the Kubena catchment area.

Ока: ?Uj|ka (GBO38), close to Kaluga.

- No good Russian origin is found for this stem. It seems that the Komi type of the word $v o j<\mathrm{PFU}{ }^{\star} \ddot{u} j i$ (Sammallahti 1988: 542) belonged to the Permic languages in Vologda, Kostroma and northern Kirov oblasts. The hydronym $U j \mid k a$ close to Kaluga is obscure. The etymology could be derived from Mordvin $u j$ 'head-, front-', Finno-Ugric * $v o ̄ j i$ 'butter, fat' (Sammallahti 1988: 551) or ‘woja 'brook' (Matveev 2001: 256-261; Saarikivi 2006: 31 ), as well. The latter is not preferable as a specific of hydronyms.

\section{Ul- 'lower-'}

Ko. $u v$ - : ul- 'lower-'; Udm. $u l$ - id. < PPerm. ${ }^{*} u l$ - id. [LG/Cs]

UDMURTIA: $U l|j u s ̌| k a\left(\mathrm{AUR}_{3} 8 \mathrm{~B}_{2}\right)$, a small river by the Vyatka in the southwestern corner of Udmurtia.

KomI: $U v^{\prime}\left|j u \sim U v^{\prime \prime}\right| j u\left(\mathrm{ARK}_{51} \mathrm{~A} 5\right)$, an upper course of the Mezen' in western Komi || Ula (ARK108G3), a large tributary of the Luza in the Jug catchment area in south-western Komi \| Ulo|m, Ulom; Bol. \& Mal. (ARK93 $\left.\mathrm{V}_{4}\right)$, headwaters of the Vilëd' in the Lower Vyčegda catchment area in western Komi $\| U l^{\prime} \mid v o z ̌(A R K 23 \mathrm{G} 8$ ), an upper course of the Verh. Dvojnik in the Pečora catchment area in northern Komi $\| U l^{\prime} \mid j u$ (ARK41B5), an upper course of the Lyža in the Pečora catchment area in Central Komi. - Af. (147-148) 'lower'.

KIrov: Ula (AKiO15B7), a tributary of the Luza, partly in Komi (see Komi), $U l \mid u j$ (AKiO17G6), a tributary of the Verh. Holunica in the Upper Vyatka catchment area in northern Kirov oblast.

Kostroma: $U l^{\prime} \mid s ̌ m a\left(\mathrm{AKO} 61 \mathrm{~B}_{2}\right)$, an upper course of the Knjažaja in the Unža catchment area in Kostroma oblast.

Vologda: Ul ozero (AVO32A1), a small lake west of lake Beloe in western Vologda oblast || Ulo|ma (AVO74 $\left.\mathrm{A}_{3}\right)$, a tributary of the Šeksna in Central Vologda oblast || Ulom|skoe oz. $\left(\mathrm{AVO}_{72} \mathrm{~V}_{2}\right)$, the source lake of the river Ulom $\mid k a\left(\mathrm{AVO}_{72} \mathrm{G}_{3}\right)$ in western Vologda oblast $\|$ Ulo $|\dot{s}| k a$ 
$\left(\mathrm{AVO}_{22} \mathrm{G}_{2}\right)$, an upper course of the Kokšen'ga in the catchment area of Vaga in north-eastern Vologda oblast. Arkhangel: Ule ša (ARK64A3), in the (Upper) Pinega catchment area. Ока: Ule $|m| k a$ (GBO118), in the catchment area of the Moskva || Ul|untus (GBO187), in the Para catchment area \|Ul|us (GBO184) in the Pronja catchment area || Ulibbiš (ARO94A1) a large tributary of the Pronja.

- Permic formants, such as $-m-<{ }^{*}-m a$ (Ulem $\mid k a<{ }^{*}$ Ule $\left.\mid m a\right)$ and -bizz (Uli|biž) < ${ }^{\star}$ bežž 'tail' (ARO94A1); i. e. 'upper course', are found in the Oka catchment area. In the name Ul|untus, the latter part -untus apparently appears in such hydronyms as Unt|us (GBO187), Unto|kor (GBO254) and in Udmurtia Unt $|e m| k a\left(\mathrm{AUR}_{2} \mathrm{OB}_{3}\right)$ and Unt em $\mid k a\left(\mathrm{AUR}_{9} \mathrm{~V}_{5}\right)<{ }^{\star}$ Unte $\mid m a$. This proves that Ulluntus has the meaning 'Lower Untus'. Because of the impossible combination - $n t$ - already in Proto-Permic (Bartens 20oo: 37-38; Sammallahti 1988: 532), the etymology of *unt(V) must be derived from a non-Permic language or it is a relic from the Pre-Permic or possibly early Proto-Permic era. In the Belozero area, also the Finnic origin $u l-<$ ‘ülä- 'upper' is possible, even more probable. Ulozero $\left(\mathrm{AVO}_{32} \mathrm{~A} 1\right)$, close to Belozero, has no outlet. Therefore it is difficult to determine its position in the water system. But a village called Verhov'e ('upper one') is located close to the lake. However, a river called Il'meza (AVO73V4) flows in the vicinity of the lake Ulomskoe oz. and the river Ulom $\mid k a\left(\mathrm{AVO}_{72} \mathrm{~V}_{2}\right)$. Ulomka (located in the lower course) and Il'meza (located in the upper course) are both tributaries of the river Šksna. This seems to suggest that the stems of names originate from the words $i l$ - 'upper' and $u l$ - 'lower'.

\section{Un- 'big'}

Ko. una 'much'; Udm. uno id. < PPerm. *艹̈na [LG], *una [Cs] id.

Udmurtia: Uni (AUR12V3), an upper course of the Lekma in the Čepca catchment area in north-western Udmurtia || Un|ja (AUR26G2), a tributary of the Nylga in the Kil'mez' catchment area.

Комг: Un'|ja (ARK92G1), a large tributary of the Pečora. - Af. (148) Ugr. un jā 'big river'.

Kostroma: Un|ža (AKO158A1), a very large tributary of the Volga.

Vologda: Un| ža (AVO6oB2), a tributary of the Sjamžena in Central Vologda oblast || Une|nga ( $\left.\mathrm{AVO}_{37} \mathrm{~V}_{4}\right)$, a tributary of the Sit' in the Kubena catchment area. 
MARIJ EL: Un|ža Un|čo < probably ${ }^{\star} U n \mid \check{z} o$ (TRM337); 1. a tributary of the Šra in the catchment area of the Ilet, 2. a tributary of the Kukša in the Vyatka catchment area.

NižNiJ-Novgorod: Un|ev Arzamas, an upper course of the Serëža close to Arza|mas \|Un|ža (AkiO43A5), a tributary of the Pižma.

OKA: Un|ar (GBO228), close to the estuary of the Kljaz'ma \| Un|gaŕ (GBO221), close to Ivanovo \| Un|gor (GBO187; ARO103B2), in the Para catchment area $\|$ Un|goŕ (GBO19o), ? Un|kura (ARO13B4) in the catchment area of the Gus' or Unža \| Un|ža (GBO191), close to the estuary of the Mokša \|Un|kar (GBO191), close to the estuary of the Mokša || Un|kor (GBO232,233,262), close to the estuary of the Mokša \| Un|oga (GBO198), an upper course of the Kljaz'ma close to Moscow \| Un|or|ka (GBO193), close to the estuary of the Mokša \| Un|uj (GBO256) in the catchment area of the Upper Mokša $\| U n \mid u r\left(\mathrm{GBO}_{256}\right)$ in the catchment area of the Upper Mokša $\| U n \mid c a(G B O 160)$, close to the city of Ryazan.

- Such Udmurt formants as -uj (Un|uj), -ur (Un|ur) and probably -č́ $i>-c a$ $(U n \mid c a)$ are found in the Oka catchment area. The Russian "cokanje" dialect in which ${ }^{*} \boldsymbol{u}>u_{j}\left[{ }^{{ }^{*}}{ }^{r}>c\right]$ is represented in the Meščëra area and there-

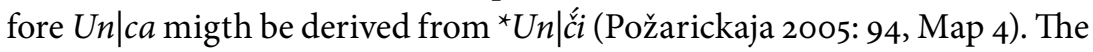
hydronym Un|ža is problematic. In Marij El the variants Unža Unčo are found. This may hint at the possibility of the original ${ }^{\star} U n \check{z}(V)$. The possible latter element $-\breve{z}(V)$ may be a formant or belong to the stem and in such a case un-cannot mean 'big'. In southern Nižnij-Novgorod oblast a possible generic -va Un|ev ? < ${ }^{\star} U n \mid v a ;{ }^{*}$ PPerm. ${ }^{\star} v a$ 'water' is found. Afanas'ev's interpretation of the component $-j a$ (Ugr. $j \bar{a}$ 'river') is not necessarily correct, because in western Udmurtia the river Unja flows as well. The location of this river seems too western for Ugric names (see Smirnov 2012: 48). Smirnov (2012: 44-45 and attached literature) points out that the formant - ja cannot always be derived from Mansi $j a \overline{~ ' r i v e r ', ~ b u t ~ c a n ~ p o s s i b l y ~ b e ~ c o n-~}$ nected with Permic ju 'river' where the Russian feminine marker - $a$ has replaced $-u$ in the end of the name. 


\section{Vil-, Vil- 'upper'}

Ko. viv- : vil- 'upper'; Udm. vil- 'upper' < PPerm. *vül [LG], *vil [Cs] 'upper-'

UdmuRtia: Vili|šur (AUR2oA2), an upper course of the Kil'mez' in Central Udmurtia.

KомI: Vil|kiša (ARK98B2), an upper course of the Lokčim in the Vyčegda catchment area in southern Komi $\| V i l^{\prime} \mid j u$ (ARK42A2), a tributary of the Synja in the Pečora catchment area in eastern Komi. - Af. (51) 'upper'.

ОкА: Vile|ma (GBO262), close to the estuary of the Mokša \|Vili|š|ka (GBO171), in the Pronja catchment area $\|$ Vili|š $\mid k a ; M a l .\left(\mathrm{GBO}_{207}\right)$, in the headwaters of the Kljaz'ma.

- Without a doubt, Vile|ma in the Oka catchment area seem to be a Permic name with the usual Udmurt formant -ma. The Vili|š names are more dubious. The formant $-\check{s}$ is more preferably of Meryan origin. The stem, however, is not Meryan, because 'upper' in Meryan has been ${ }^{\star} i l$ - or ${ }^{\star} v e r$ (Rahkonen 2012: 38).

\section{Vož- 'tributary, branch'}

Ko. vož 'branch, tributary'; Udm. vož 'estuary, junction' < PPerm. ${ }^{*}$ vož [LG], *vว̌ [Cs] 'branch'

UDMURTIA: Vož (AUR16B2), an upper course of the Lysva in north-eastern Udmurtia || Vožoj|ka (AUR28B3), a large tributary of the Pozim in the Iž catchment area close to Iževsk.

Komi: Voža|jol' (ARK69B5), a small tributary of the Vesljana in the Vym' catchment area in Central Komi. - Af. (45-46) 'tributary'.

Kostroma: Vožlega (AKO78B3), a tributary of the Nolja in the catchment area of the Kostroma close to Galič in western Kostroma oblast || Vože|ra (AKO86A1), a large tributary of the Monza in the catchment area of the Neja in Central Kostroma oblast \|Vož|na (AKO52B2), a tributary of the Solda in the Kostroma catchment area in north-western Kostroma oblast || Vožo|ra (AKO133A2), a tributary of the Neja in Central Kostroma oblast.

Vologda: Vož|bal (AVO62A1) and its upper course Vož|bal|ec (AVO41V4), the left branch of the Careva in the Sukhona catchment area in Central Vologda oblast || Vož|duga (AVO41V5), a tributary of the Vožlbal, see 
above || Vože oz. (AVO14B33), the source lake of the River Onega-Sujda in northern Vologda oblast || Voželga (AVO15V4), a large branch from the lake Vože to the east \|Vože $m \mid k a\left(\mathrm{AVO}_{45} \mathrm{~V}_{5}\right)$, a tributary of the Sel'men'ga in the catchment area of the Sukhona in eastern Vologda oblast.

OкA: Voža (GBO161; $\mathrm{ARO}_{30 \mathrm{~A}}$ ), a large tributary of the Oka close to Ryazan || Voža|tel' (GBO268), in the catchment area of the Tëza \| Vožlgora (GBO17o) close to Ryazan \|Vože|nka (GBO211) close to Vladimir || Vož|n|oe (GBO13o ? Voža AVLO94B4), empties into lake Velikoe in the Pra catchment area \|Vož|nja (AVlO59A4), an upper course of the Sudogda-Jada close to Sudogda.

- It is obvious that the stem $v o \check{z}$-can be derived from the PFP-level word *voša 'fork, branch' (Sammallahti 1988: 554). The problem is that the word ${ }^{*} v o z ̌(V)$ may appear in Meryan rather similarly to the Permic word vož 'branch'. At least the hydronyms Voža (GBO161) and Vož|gora (GBO17o) seem to be too far from the Meryan core area and could be Permic. On the other hand, at least the hydronyms Vož|bal (AVO62A1), Vož|bal|ec $\left(\mathrm{AVO}_{41} \mathrm{~V}_{4}\right)$ in Vologda oblast and Vože|ra (AKO86A1) and Vožo|ra $\left(\mathrm{AKO}_{133} \mathrm{~A}_{2}\right)$ in Kostroma oblast, with their non-Permic formants - bal and -ra (see Rahkonen 2012: 23-24, 32-34), seem to be of Meryan-Muroma not Permic - origin.

\subsection{Some special questions}

Considerable evidence of the relatively western location of ancient Permic speakers can be found in the Finnic layer of borrowings in the ProtoPermic language (Bartens 2000: 16-17; Saarikivi 2006: 52). The contact area has most probably been somewhere in the Russian North. According to Atamanov (2001: 119-127), some of the Udmurt clans (being connected with the cult of voršuds), e. g. Čudna and Čud'za, seem to originate from the same area as well. However, these families may have their origin in the Volhov area, belonging to a non-Finnic Čudian population (Rahkonen 2011). Within the boundaries of the Kirov and Vologda oblasts, there are such villages as Čegadolevskij (cf. Čagoda rivers in Volhov and Svir' regions) and Čudallovo (cf. Čud toponyms in the Volhov, Tihvinka and Msta catchment areas) (see Rahkonen 2011: 247-248). The language of these Čuds may still have been close to Middle Proto-Finnic, having the 
sibilant $\check{s}$ and the affricate $\check{c}$. The voršudic clans mostly originate from three regions: east of Kazan [Arsk], between Vjatka and Iževsk [Kalmez], from the Čepca [Vatka] catchment area and some of them from the Russian North (Atamanov 2001).

Another question is the boundary between stems and formants. Mullonen (personal communication) has found some of the cases problematic: e. g. Ičal|ka (GBO264), Ire|ka (AKiO64A3), Ker|ec (AKiO16G6), $S_{i n}|d| j u k$ (AKO19A2), Śur|sa (ARK96B1), Voj|čliha (AKiO17V4), Voža|tel' (GBO268). Some of them could be explained differently as Ireka < ${ }^{\star} \operatorname{Ir} \mid j e k a$, but in Kirov oblast ${ }^{\star} j e k a$ 'river' is not probable and definitely not of Permic or Mari origin. Mullonen (personal communication) notes that the Russian suffix $-k a$ is regularly connected with the stem directly after a consonant, not after a vowel. However, one should note that $-k a$ may have been linked to originally Permic names during a bilingual period by originally Permian people. In that case, the regular rules of the Russian language may not always have worked. The origin of Sursa might be $<\mathrm{Udm}$. *'ures 'way, pathway', wherein the second vowel disappeared and the Russian feminine - $a$ was added to the end of the name. In any event, I prefer the Udmurt development sur 'watershed' + formant $-s a$, because it requires less explanation. If there is no good reason to think otherwise, I have followed the rule of thumb that "the easiest is the most probable”. In some Mari and Udmurt dialects $j \sim d$ ' (e. g. Bartens 2000: 46) and in regular Udmurt and Komi, Fi paju Udm./Ko. bad' (ibid. 2000:39). Accordingly, Sin'djuk could be explained as śin|d’uk 'spring river'. Voža|tel' can be interpreted as *Voža|tí|läj 'branch lake river' (with Mordvin läj 'river') or Vožat $\left|j e l<{ }^{\star} V o z ̌ a t\right| j i l$; *jil 'upper source' (Atamanov 1988: 80). But one should remember that there is an Udmurt word tèl' '(young) forest' (ibid. 1988: 66) that in my opinion seems more probable. One of my principles has been: If a hydronym cannot be interpreted to be of Russian, Mordvin, Meryan or Mari origin and the distribution together with the lexicon and the formant allow interpreting it as Permic, these factors determine the boundary between the stem and the formant. 


\subsection{Discussion}

Stems of Permic hydronyms can be found in the eastern parts of the Vologda and Kostroma oblasts, as pointed out above. The westernmost boundary runs through the Vologda oblast, slightly east of the lakes Vože and Kubena to the south-east (Map 1). In fact, the names of both of these lakes are possibly, but not necessarily, of Proto-Permic origin, cf. Ko. gibad 'marsh' (Lytkin-Guljaev 1970 s. v. zыбad) < PPerm. ${ }^{*}$ güb- < ${ }^{\star} k u m p-$ and PPerm. ${ }^{\star} v o z ̌ ~[L G]$ or $v o z ̌ ~[C s] ~ ' b r a n c h '$. The lake Kubena is surrounded by marshes and the Vože is one of the main crossroads to the north, south and east. However, it is possible to find other alternatives as well: for example $<{ }^{\star} k u \beta(V)$ 'long', ? originating from the language of Veś or some unknown Finno-Ugric $x$-language (see Rahkonen 2013: 35) spoken in ancient times in the northern Russian lakeland; cf. Mord. kuva|ka 'long'. The origin of ${ }^{*} v o z ̌(V)$ can be Meryan or some local ancient Finno-Ugrian language which was spoken in the northern Russian lakeland. In Kostroma oblast, the boundary runs through the upper course of the river Kostroma to the south-east ending in the estuary of the Unža (Map 1). There are folk stories supporting the idea of a Permian population having lived by the river Unža (Ahlqvist 2001a: 240).

Almost all of the 29 stems of hydronyms that are presented above can be found in the Oka catchment area as well. Their location follows rather identically the boundary of the ethnonym Meščëra (see Map 1 above according to the data of GBO). Not only are plenty of Permic stems found in the Oka catchment area, but several Udmurt formants connected to the above-mentioned stems, too, such as: -mes $\sim-m a s>-m i s,-u r,-i m,-p a \sim$ $-b a,-i \check{c},-m a n,{ }^{*}-s i>-s a,-c ̌ i,-m a,-u j,-m a$ and $-b a s ̌$. Thus, my claim (2009) that a Permic language was spoken in the Oka catchment area is very justified and by no means speculative.

According to Atamanov (1988: 80), the formant -baš originates from the Tatar language, which means that at least some of the Permic hydronyms are quite recent. However, it is possible that the formant -baš may sometimes have developed through a Meryan-Muroma adaptation from the Permic word 'tail, upper course': PPerm. ${ }^{\star} b \dot{g} z \check{z}[\mathrm{LG}]>$ Komi bež $\sim$ Udmurt biž. In Yaroslavl oblast, such formants with irregular vocalization as Vorgo|baš (AJO106B1), Im|buš|ka (AJO76B4), Ino|paš (AJO47B3), Ki|boža $\left(\mathrm{AJO}_{71} \mathrm{~B}_{4}\right), N i|b o z ̌| k a\left(\mathrm{AJO} 97 \mathrm{~B}_{1}\right), U l e \mid p i s ̌ s(\mathrm{AJO} 87 \mathrm{~A} 1)$ are found. This irregularity may hint at a substrate origin. 
There are stems which refer to a very early origin, probably to the era of the Anan'ino Culture in the early Iron Age. Such stems are e. g. tojma-, $i z$ - and sod- which seem to be derived from Proto-Permic forms ${ }^{*}$ tojma 'neck of land' (Rahkonen according to the vocalization of E. Itkonen 1954) and ‘śod 'black' (Lytkin-Guljaev 1970 s. v. cъöd). Tojma and Sod hydronyms deviate from their modern descendants Udm. tujmi and Udm./Ko. sed 'black', which, through the Russian adaptation, usually has the form ced- [sed-]. The westernmost location of the toj(ma) and sod hydronyms is slightly west of most of the other Permic stems (Map 1). It is probable that $I \check{z}(m a)$ hydronyms < PPerm. ${ }^{\star} e \check{c}$ a 'meadow' or *e ${ }^{\star} \check{z}$ 'massive, broad', are very old as well.

\section{Generics -ju, -(j)uk and -(j)ug}

Matveev (1965: 211) has presented a hypothesis that the hydronyms with the generic -juk or -jug(a) in the eastern Vologda and Kostroma oblast and in Kirov oblast are of old Permic origin from the era of the Anan'ino Culture (ca. 800-300 BC). It seems that later he abandoned this hypothesis and presents that the origin of the formant is unsolved (ibid. 2001: 254). The basic problem is that usually the word *juka or *joka 'river' is reconstructed in Proto-Permic as ${ }^{\star} j u$ (e. g. Lytkin-Guljaev 1970 s. v. ${ }^{\star} \wp$ ). This suggests that the latter syllable already disappeared from the common proto-language. However, Matveev has pointed out that even in the Komi territory, some modern hydronyms with $-j u$, according to old documents, still had the form -juga in the 15th-17th centuries (Matveev 2001: 255).

The generic - $j u$ is rare, practically non-existent, in Udmurt hydronyms. Instead, -šur 'river' is most often used in names of rivers (AUR). In Komi hydronyms the generic - $j u$ is very usual (see Appendix). Noteworthy is that west of Komi Republic and Udmurtia the generic -jug(a) is found in a continuous and compact area in the eastern Vologda and Kostroma area and in the western Kirov oblast (Map 2). B Below I call this area the "West Permian Territory" [WPT]. It is obvious that in European Russia the generic -jug(a) originates as judged by the stems and areal distribution at least from three different linguistic backgrounds: 1) Permic of WPT (see below), 2) Muroma (Rahkonen 2012: 38) and 3) northern unknown language especially in Arkhangelsk oblast (Saarikivi 2006: 30). All of them have been Uralic languages, but not very close relatives. These all can be derived from Proto-Uralic ^jukå 'river' as reconstructed by Sammallahti (1988: 537). 
The generic $-j u g(a)$ is found to some extent in the peripheral areas of Komi [mostly in the western rajons, Priluzkij, Udorskij, Ust'-Cilemskij and Ižemskij] (Afanas'ev 1996, ARK) and Udmurtia [mostly in the Kil'mez' region] (AUR), and continuously in the hydronyms of the WPT area (Map 2). In the Komi Republic most of the official -jug(a) hydronyms also have a Komi form with -jug(a) (Afanas'ev 1996). There are some exceptions, such as Loptjuga (official) Lopi ju (Komi) and Južnaja Cep"juga (official) Lun Čeb"ju (Komi), both in Udorskij rajon. In some cases, old but later disappeared courses of rivers have provided names for villages, such as Muft|juga (official) < ${ }^{\star} M u k|t i| j u g \sim M u k \mid t i$ (Komi) [first mentioned in the year 1608 as being located in Udorskij rajon] (ibid.) even though nowadays no such river exists.

In WPT, the specifics of the -jug hydronyms can usually be derived from Permic languages. There are also several specifics whose etymological origin is opaque, as noted by Matveev (2001: 254), but this situation should be normal for toponyms everywhere. If the Permians were newcomers in WPT, they most probably used semi-calques to change several generics based on the previous language, but left many of the stems in use. This happens everywhere in such an occasion (e.g. Mullonen 2002: 105-139). For instance, the following specifics, probably of Permic origin, are found in WPT connected with the generic -jug (PPerm. reconstructions are Lytkin-Guljaev's from 1970):

An- < Ko./Udm. an < ${ }^{\star} a \eta$ 'jawbone' (Afanas'ev 1996: 21) $\|$ Pol- < Ko. pol' < ${ }^{\star} p \dot{o} l '$ 'old man's or Ko. poloj 'sound, intermediating river' (ibid. 1996: 126) || Vož- Ko. vož 'tributary', Udm. 'estuary' || Voz- < Udm. voź 'meadow' || Je- < Udm. je, Ko. ji 'ice' \| Ki < Ko. -ki (ibid. 1996: 71), Udm. ke 'stone' || Kort- < Ko. kert (ibid 1996: 79), Udm. kort 'iron' || Kost- < Ko. kost < PPerm. *kost 'gap, middle' || Kuz- < Ko./Udm. kuź 'long' || Pič- < Udm. piči 'little' (ibid. 1996: 124) || Paž- < Udm. pož, Ko. pež 'dirty' || Port- < Ko. pert 'pot' || Siv- < unknown origin, but in Udmurtia one of the main rivers is called Siva \|Pun- < Ko. pun 'fat' || Piž- < Ko./Udm. piž '(row)boat' || Jur< Ko. jur 'upper source' || Ver- < Ko. ver 'forest' || Kar- < Ko./Udm. kar '(ancient) fortress' || Koč- < Udm. kočo 'magpie' or Ko. kedž 'bend of river' (ibid. 1996: 193) || Lupt- < Ko. lep : lept- 'rubbish from woods' || Mat- < Ko. mate 'close, near' || Mič- < Ko. mič 'beautiful' (ibid. 1996: 105) || Njur-< Ko./Udm. ńur 'marsh' || Puč- < Udm. puč 'pole' || Už- < Ko./Udm. už 'stallion' || Ač- < PPerm. *aร̌ 'meadow' || Murd- < Udm. murdo 'fish trap' || Vaz- < Udm. vaź 'spelt (wheat)' || Sord- < Ko. sord 'forest' $\|$ Čr $r$ - Ko. čir 'species of fish.'? 
Why in Komi and Udmurt was the development Proto-Finno-Permic [PFP] ${ }^{\star} j u k i>$ ?Pre-Perm. ${ }^{*} j u g>$ PPerm. and Komi/Udmurt $j u$, but in WPT ${ }^{*} j u k i>^{*} j u g ?{ }^{10}$ Two different explanations may be suggested. It is possible that in Proto-Permic the word still was jug 'river' and ju was developed later simultaneously in Komi and in Udmurt. Actually the Proto-Permic reconstruction PFP ${ }^{\star} j u k i>$ PPerm. ${ }^{\star} j u$ do not lay on a firm ground, because the word $j u$ in Udmurt occurs only in a compound word ju-šur, but not independently (Lytkin-Guljaev 1970 s. v. ю).

The previous idea of Matveev that these hydronyms originate from the Anan'ino period seems unlikely, because the specifics connected with the generic -jug seem to be in many cases too recent - not Proto-Permic. It is reasonable to think that a Permic language was spoken at least still in the late Middle Ages in WPT. In my opinion, there was a separate Permic linguistic group that could be called "West Permic". It is probable that this population was called зырян [zyryan] by Russians, along with the Komi people. Matveev (2001: 69-70) has presented that in the Vaga catchment area, north of the river Sukhona, there is an area where the inhabitants of 30 villages are called $3 ы р b\left[z y r^{\prime}\right]$. Permic hydronyms are found in that area as well (see Maps 1 and 2).

Sjögren (1861: 61) collected folk stories from the Kotlas area, which mention an ancient people known as Gam in WPT. Nowadays, there are villages called Gam located in the Ižemskij [1763] and Ust'-Vymskij [1586] rajons in the Republic of Komi (Afanas'ev 1996 s. v. ГaM). The ethnonym gam could be derived from ${ }^{\star} k a m \sim K o m i$; cf. Csúcs' (2005) suggestion of PPerm. ${ }^{\star} k ⿰ m i$ 'man'. In that case, the ethnonym gam $\sim$ ? kam was used as an endonym, but Slavs and Finnic tribes (Veps and Karelian) used the name zyryan $\sim$ syrjääni equally with Komi $\sim$ Zyryan. But at the same time, one should remember that the Permians living by the upper course of the river Unža were called Votyak, i. e. Udmurt (Ahlqvist 2001a: 240).

One should note that the "apostle" of the Komi people, Stefan Permskij (circa 1340-1396), was born in WPT in Velikij Ustjug (see here and below Fedotov 1991). He - or he along with his students - translated sacred texts into Permic and created the old Permic alphabet. In order to do all this he must have known the language very well. It has been suggested that his mother was Permian, coming from Velikij-Ustjug. As presented by Fedotov, it is most probable that Stefan learned the language in his childhood in Ustjug, having been bilingual. It is noteworthy that later he moved to Rostov and then to Moscow to study theology and 
Greek language and created the abur alphabet when he was already in the monastery in the year 1372, at the age of around 32 years (Bartens 2000: 20)! On these grounds, it seems that Stefan would have been a native Permic speaker and that a Permic language was still spoken in the territory of Velikij-Ustjug at least in the late Middle Ages. Speakers of this West Permic language, or of a western Komi dialect spoken in WPT, seem to have preserved the archaic form ${ }^{\star} j u g$ in their speech or at least in their toponyms.

The question of the Permic origin of the -jug generics of the Oka catchment area is difficult to solve, because it is obvious that the Muroma language had a similar (in appearance) word jug(a) 'river' as well (Rahkonen 2012: 38). I did not analyse these any further, because the risk of making mistakes is too high. As stated above, several Permic stems of hydronyms are found in the Oka catchment area (most of the 29 common Permic stems presented above). It seems that the Permic language here was closer to Udmurt than Komi. There are some hydronyms which may reflect the ethnonym $U d(-m u r t)$. These include $U d$ (GBO270), $U d a\left(\mathrm{GBO}_{187}\right)$, and especially $U d \mid v a(\mathrm{GBO} 241)$; cf. PPerm. *va 'water', Ud|evskoj (GBO193), Ud|ovo (GBO233), and $U d \mid$ ovskoj (GBO105). I am aware that there is a Russian word $y \partial a[u d a]$ 'hook and line', which is a very suitable motif for naming as well. However, in Marij El and in the eastern corners of Kostroma and Vologda oblasts, the ethnonym odo 'Udmurt' is found without the latter element of the ethnonym murt (Atamanov 1988: 10-11; 2010: 65, Map). This fact makes it very possible that the ethnonym $U d$-(murt) < Proto-Udmurt ${ }^{\star}$ od (SSA III s. v. votjakki) was known in the Oka catchment area, too.

It should be noted that a number of hydronyms with the Permic generic - va 'water' are found in the Oka catchment area; e.g. Kalja|va (GBO219) 'gull water', Kuzo|va (GBO105) 'long water', Mura|va (GBO236) 'deep water', Piža $|v| k a<{ }^{*} P i z ̌ a \mid v a$ 'rowboat water' (GBO236), Pož|va (GBO186) 'muddy water', Ud|va (GBO241) 'ud-murt water' and Ur|va (GBO191) 'squirrel water'. Also possible is a Permic adaptation Mosk|va $\left(\right.$ GBO102) < from Meryan-Muroma ${ }^{*} M o k s a$; cf. Permic development *-ks > sk (Lytkin-Guljaev 1970: 21). Corresponding Moksa hydronyms are found on the border of Vologda and Yaroslavl oblast (AJO22B2), and Moksa (AKO109B2) is also found in the Kostroma oblast in the traditional Meryan territory. It is possible that both Moksa and Mokša are composed of two elements ${ }^{*} m o$ 'land' and the formant $-k s a$ or $-k \check{s} a$. The 


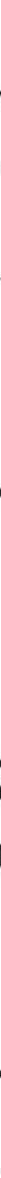

Map 2: Distribution of hydronyms with the ending -jug(a)

fact that in the Meryan-Muroma language historical ${ }^{\star} a>{ }^{\star} o$ (Rahkonen 2012: 17) makes this hypothesis phonetically possible $\left[{ }^{*} m a>{ }^{*} m o\right]$. Both the Mokša and the Mosk|va $<$ ? ${ }^{*} M o k s a-v a$ were important transition rivers between the Oka-Sura and Oka-Volga systems, and the transition ran over a neck of land. Therefore, the motif "Land River" is most suitable. 


\section{Conclusions}

The more western spread of ancient Permic hydronyms compared with earlier studies (A. K. Matveev 1965; 1999; L. N. Žerebcov 1982: 26-4O, N. D. Kabinina 2011 and A. Turkin 1971: 277-283; Atamanov 2010) seems obvious in the light of hydronyms. Most probably, Permian groups were living in the past in almost all of the catchment areas of the Sukhona and Unža. This can be seen in the spread of the 29 selected stems of hydronyms (Map 1) and the hydronyms with a Permic stem attached with the generic -jug(a) (Map 2). The word jug 'river' seems to have still been in use in the north-western Permic language (or Komi dialect) during the Middle Ages. This fact also makes us reconsider whether the word $\star_{j u}$ already existed in every dialect of Proto-Permic, as has usually been presented (LytkinGuljaev 1970; Sammallahti 1988; Csúcs 2005), or if the more archaic form ${ }^{*}$ jug survived in the north-western dialects. In addition, the ethnomym $z y r^{\prime}\left(<{ }^{*}\right.$ Zyrjan) is used to refer to inhabitants of approximately 30 villages in the Vaga catchment area slightly north of the river Sukhona. The biography of Stefan Permskij, the founder of the old Permic alphabet, who was born in Velikij Ust-Jug, shows that a Permic language was most probably still spoken by the river Sukhona in the late Middle Ages. The folk stories from the Kotlas area (in the Lower Sukhona), which were collected by Sjögren in the 19th century and which mention an ancient ethnos gam that can be interpreted as ${ }^{\star} k o m i$, may provide proof of an ancient Komi inhabitation in the lower course of the Sukhona. The more western location of Permic speakers makes the linguistic contacts and borrowings with Finnic speakers even more understandable than what has been assumed until now.

The question of whether the language of the Meščëra tribe by the lower and middle course of the river Oka was Permic is rather clear in the light of the presented material of 29 common Permic stems of hydronyms and several Udmurt formants. In addition, there are some hydronyms which seem to be based on the ethnonym $u d$-; cf. $U d$-(murt). Critics should point out what else, if not Permic, the linguistic background of the Meščëra tribe could be and not only present their doubts. The Permic alternative based on hydronyms is better justified than any other suggestion posited up until now.

Pauli Rahkonen

<pauli.rahkonen@gmail.com> 


\section{Notes}

1. The words of the song translated into English are: "Čeremises (i. e. Maris) and Votyaks (Udmurts) were fishing in the river, in the river and the mother (i. e. the river Unža), they were good-looking young men”.

2. A formant is a final element in a name which may be derived from a derivational suffix or in many cases modified generic of a toponym. For instance the formant $-g a$ in the names of rivers often represent the word (generic) ${ }^{\star}$ joga or ${ }^{\star} j u g a$ 'river' (Matveev 2001: 249-256; Saarikivi 2006: 30). The final element - $m$-, in turn, is a common suffix in Finno-Ugrian languages often occurring in an aspect of a formant.

3. Finno-Ugrian hydronyms usually consist of two elements, for instance Valkealjärvi 'White Lake' in Finnish, where valkea (white) is a specific and järvi (lake) is a generic.

4. In a bilingual situation, a new prestige language tends to replace the former generic of the receding language with its own word (e.g. ozero in Russian), see e.g. Mullonen 2002: 105-139.

5. Voronceva and Galkin (2002: 337) present an idea that the hydronym Unčo Unža Unžinka is derived from Selkup undža 'brook'. A Selkup origin is impossible to accept, but it is possible that there has been a corresponding word in some ancient Uralic language. The word has possibly been lost in other languages, according to the distribution most probably in the Permian languages.

6. In Nižnij-Novgorod oblast, the names after hydronyms refer to the closest center of an administrative district.

7. Usually, after a sibilant and affricate $-j u g(a)>-u g(a)$.

8. In Finnish toponyms, the corresponding specific äijä(n)- 'old man('s) is rather usual (NA).

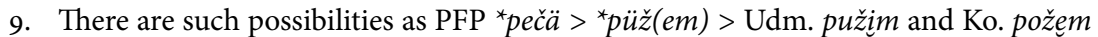
$\sim$ Fi. petäjä (see Sammallahti 1988: 553) 'pine' > piž in toponyms and PFP * $p u c ̌-k i \sim$ Fi. putki 'hollow stem' (ibid. 1988: 539) > puč-.

10. The final $a$ is probably a later Russian feminine marker.

\section{References}

Afanas'ev 1996 = А. П. Афанасьев: Топонимия республики Коми. Сыктывар.

AhlQVist 1997 = Арья Альквист: Мерянская проблема на фоне многослойности топонимии. - Вопросы Языкознания 1997 № 6: 22-36.

- 2001a: Kertomuksia Keski-Venäjältä III: Unžan jokivarrella. - Journal de la Société Finno-Ougrienne 89: 227-249.

- $2001 \mathrm{~b}=$ Арья Альквист: Субстратная топонимия Ярославского Поволжья. Очерки исторической географии северо-запад России. - А. С. Герд \& Г. С. Лебедев (eds): Славяне и финны. Санкт-Петербург: Издательство С. Петербургского университа. 
Aiкio, ANTe 2012: An Essay on Saami ethnolinguistic prehistory. - Riho Grünthal \& Petri Kallio (eds): A Linguistic Map of Prehistoric Northern Europe. Suomalais-Ugrilaisen Seuran Toimituksia 266. Helsinki: Suomalais-Ugrilainen Seura. 63-117.

ATAMANOV 1988 = М. Г. Атаманов: Удмуртская ономастика. Ижевск: Удмуртия.

- 2001: По следам удмуртских вормудов. Ижевск: Удмуртия.

- 2010: Происхождение удмуртского народа. Ижевск: Удмуртия.

Bartens, Raija 200o: Permiläisten kielten rakenne ja kehitys. Suomalais-Ugrilaisen Seuran toimituksia 238. Helsinki: Suomalais-Ugrilainen Seura.

Chalikow A. CH. 1992: Vom Einfluss der Aselino-Ananjino-Kultur auf die Ethnogenese der Mari. - Journal de la Société Finno-Ougrienne 84: 53-64.

CsúCs, SÁNDOR 2005: Die Rekonstruktion der permischen Grundsprache. Budapest: Akadémiai Kiadó.

DAL' 1880-82 = Владимир Даль: Толковый словарь живого великорусского языка I-IV. Санкт-Петербург: Издание книгопродавца М. О. Вольфа.

ESRJ 2003 [1950-1958] = Макс Фасмер: Этимологический словарь русского языка. 2. том. Москва: Издательство Астрел · Аст.

Fedotov 1991 = Георгий П. Федотов: Стефан Пермский. - Святые Древней Руси. Москва. <www.vehi.net/fedotov/svyatye/index.html>.

GBO 1976 = Г. П. Смолицкая: Гидронимия бассейна Оки. Москва: Издательсто Наука.

ItKonen, ERKKi 1954: Zur die Gesichte des Vokalismus der ersten Silbe im Tscheremissischen und in den permischen Sprachen. Finnisch-Ugrische Forschungen 31. 149-345.

KABININA 2011 = Надежда Кабинина: Субстратная топонимия Архангельского Поморья. Труды Топонимической экспедиции. Екатеринбург: Издательство Уральского университа.

KIRILLOVA 2002 = Людмила Кириллова: Микротопонимия бассейна Кильмези. Ижевск: Урдмутский институт истории, языка и литературы УрО РАН.

Kiviniemi, Eero 199o: Perustietoa paikannimistä. Helsinki: Suomalaisen Kirjallisuuden Seura.

Lytkin - GulJaev 1970 = В. И. Лыткин \& Е. И. Гуляев: Краткий этимологический словарь коми языка. Переиздание с дополнением. Сыктывкар: Коми книжное издательство.

MAKSIMOV - DANILOv - SAARINEN 2008: Udmurttilais-suomalainen sanakirja. Turun yliopiston suomalaisen ja yleisen kielitieteen laitoksen julkaisuja. Turku.

Matveev 1964 = А. К. Матвеев: Субстратная топонимика Русского Севера. - Вопросы Языкознания 1964 № 2. Москва.

- 1965: Есть ли древнепермская топонимика в Заволочье? - Советское ФинноУгроведение 3/1965: 207-212.

- 1999: Древнее население севера европейского части России. - Опыт лингвоэтнической карты 1. Известия Уральского государственного университета. Гуманитарние науки, Вып. 2. 13/1999. 80-88.

- 2001: Субстратная топонимия Русского Севера Часть I. Екатеринбург: Издательство Уральского университа. 
Mullonen 2002 = И. И. Муллонен: Топонимия Присвирья. Проблемы этноязыкого контактирования. Петрозаводск: Российская академия наук Карельский научный центр Институт языка, литературы и истории.

$\mathrm{NA}=$ Kotimaisten kielten keskuksen nimiarkisto. Institute for the Languages of Finland. Archive of toponyms.

PaAsonen, HeIKKI 1990-96: Mordwinishes Wörterbuch 1-4. Zusammengestellt von Kaino Heikkilä. Lexica Societatis Fenno-Ugricae XXIII. Helsinki. Suomalais-Ugrilainen Seura.

Patrushev, Valery 200o: The Early History of the Finno-Ugric Peoples of European Russia. Oulu: Societas Historiae Fenno-Ugricae.

PožARICKAJA 2005 = С. К. Пожарицкая: Русская диалектология. Москва: Академический проект.

Rahkonen, Pauli 2009: The linguistic lackground of the Ancient Meshchera tribe and pricipal areas of Settlement. - Finnisch-Ugrische Forschungen 60: 162-202.

- 2010: Finno-Ugric Hydronyms of the River Volkhov and Luga catchment areas. Suomalais-Ugrilaisen Seuran Aikakauskirja 93: 205-266.

- 2012: Границы распространие меряно-муромских и древнемордовских гидронимов в верховях Волги и бассейне Оки. - Вопросы Ономастикии 1/2012: 5-42.

- 2013: South Eastern Contact Area of Finnic Languages in the Light of Onomastics. Jyväskylä: Bookwell.

RJABININ = E. А. Рябинин 1997: Финно-угорские племена в составе древней Руси. Санкт-Петербург: Издательство Санкт-Петербургского университа.

SAARIKIVI, JANNE 2004: Über die saamischen Substratennamen des Nordrusslands und Finlands - Finnisch Ugrische Forschungen 58: 162-234.

- 2006: On the Uralic substrate toponymy of Arkhangelsk region: problems of research methodology and ethnohistorical interpretation. - Substrata Uralica. Studies on Finno-Ugrian substrate in northern Russian dialects. Tartu: Tartu University Press.

Sammallahti, Pekka 1988: Historical phonology of the Uralic languages. - Denis Sinor (ed.): The Uralic languages. Leiden. 478-554.

Sjögren, Johan Andreas 1861: Über die Älteren Wohnsitze der Jemen. - Gesammelte Schriften Band 1, Historisch-etnographische Abhandlungen über den finnisch-russischen Norden. Kaiserliche Akademie der Wissenschaften. St.Petersburg.

SMIRNOV 2012 = О. В. Смирнов: Субстратная мансийская топонимия на территории былого проживания манси. - Вопрсы Ономастики 2/2012: 43-79.

- 2013: К вопросу о пермском топонимическом субстрате на территории Марий Эл и в бассейне среднего течения реки Вятки (в свете этнической интерпретации археологических культур). 1. - Вопросы ономастики 2/2013: 7-59.

- 2014: К вопросу о пермском топонимическом субстрате на территории Марий Эл и в бассейне средного течения реки Вятки (в свете этнической интерпретации археологических культур). 2. - Вопросы ономастики 1/2014: 8-33.

SSA 1-3 1992-200o = ERKKI ITKONEN \& Ulla-MAIJA Kulonen (eds): Suomen sanojen alkuperä. Etymologinen sanakirja. Suomalaisen Kirjallisuuden Seuran Toimituksia 556, Kotimaisten kielten tutkimuskeskuksen julkaisuja 62. Helsinki: Suomalaisen Kirjallisuuden Seura - Kotimaisten kielten tutkimuskeskus. 
Tret'JAKov 1966 = Третьяков, П. Н.: Финно-Угры, Балты и Славяне на Днепре и Волге. Москва: Издатеьство „Наука“.

TRM 2002 = О. П. Воронцева \& И. С. Галкин: Топонимика Республики Марий Эл. Йошкар-Ола: Издательство Марийского полиграфкомбината.

TURкIN 1971 = Адольф Иванович Туркин: Архаическая лексика Коми языка в топонимике Вычегды. Таллин: Академия наук Эстонской ССР.

ŽEREBCOV 1982 = Л. Н. Жеребцов: Историко-культурные взаимоотночения коми с соседними народами X - начала ХХ вв. Москва.

\section{Maps}

AJO 2002 = Атлас Ярославской области. Роскартография. 1:100 ооо. Москва.

$\mathrm{AKiO} 2007$ = Атлас Кировская Область. ФГУП верхневолжское аэрогеодезическое предприятие. 1:200 ооо. Нижний Новгород.

AКО 2009 = Атлас Костромской области. Роскартография. 1:100 ооо. Тверь.

AMO 2007 = Атлас Московской области. Роскартография. 1:10о ооо. Москва.

ARK 2006 = Атлас Республика Коми. ФГУП «Аэрогеодезия». 1: 200 ооо. СТ. Петербург.

ARO 2006 = Атлас Рязанской области. Роскартография. 1:100 ооо. Москва.

AUR 2007 = Атлас Удмуртская Республика. ФГУП Уралаэрогеодезия. 1:200 ооо. Екатеринбург.

AVLO 2008 = Атлас Владимирской Области. Роскартография. 1:10о ооо. Тверь.

AVO 2008 = Атлас Вологодская область. ФГУП «Аэрогеодезия». 1:200 ооо. СТ. Петербург.

ГУГК СССР/ Онега 1990: ГУГК. 1:500 ооо. Ленинград.

ГУГК СССР/ Котлас 1990: ГУГК. 1:1 ооо ооо. Ленинград..

$\mathrm{NN}=$ Общегеографические карты Российской Федерации 1995: Федеральная служба геодезии и картографии России. Нижегородская Область. 1:1 ооо ооо. Москва.

Arkhangel = Архангельская Область. Общегеографические карты Российской Федерации 1994: Федеральная служба геодезии и картографии России. 1:500 000. 


\section{Appendix}

$-j u$

Udmurtia: $V^{\prime} \mid j u$ AUR19A3, Ju|šur AUR13 $\mathrm{A}_{5}$

Komi: $A n^{\prime \prime} \mid j u$ ARK81B4, Anib|ju 88B1, An'|ju 81B4, Bad'|ju ARK55V6, 25B6, 98B3, Balban"ju ARK43B6, Bol. Veža|ju ARK52V2, Bol. Kejn"|ju ARK25V7, Bol. Kozla|ju ARK41B8, Bol. Lem"|ju ARK85G4, Bol. Mičalju ARK41G5, Bol. Niedz'|ju 19D7, Bol. Pjatomboj|ju ARK19V6, Bol. Sed'|ju ARK51B7, Bol. Soj|ju ARK61B6, Bol. Hojlalju 19G8, Bol. Čiv'|ju ARK75G5, Bol. Jarzi|ju ARK18B4, Vangirr"|ju ARK42G3, Van'|ju ARK17G4, Ved'|ju ARK71A5, Veža|ju ARK49V8, 31G7, 9oV2, 56V1, Vež"|ju ARK8oG2, Vez"|ju ARK71G4, Vel'|ju ARK6oG4, Ven'|ju ARK49V8, Verh. Vidz'|ju ARK44V1, Verh. Kir "ju ARK $71 V_{5}$, Verh. Mirt'|ju ARK96A2, Verh. Dzëlja|ju ARK28G2, Verh. Kus'|ju ARK94V2, Verh. Lèn"|ju ARK46B1, Verh. Moš"|ju ARK38B3, Verh. Sej|ju ARK47V6, Verh. Sjuz'|ju ARK45G6, Verh. Turun"|ju ARK106V3, Ver'|ju ARK9oV2, 85A5, Vet'|ju ARK68B2, Vidz'|ju ARK104B2, 38V2, 106B2, Vlasej|ju ARK4oA2, Vozej|ju ARK16G2, Von"|ju ARK55G6, Vor'|ju ARK96G3, Vilis-Kojlju ARK46V3, Vil'|ju ARK42A2, 33V6, V'|ju ARK79B6, Veralju ARK42G4, Ver"|ju ARK98V1, Gaz"|ju ARK68V3, Gerd'|ju ARK62A2, Glaz"|ju ARK6984, Gnet'|ju ARK13V7, Gnilaja Uv'|ju ARK51A5, Grubelju ARK27V7, 28G1, 19D7, Gudir"|ju ARK4oG2, Gèrd"|ju ARK42G3, Džëlja-Kos"|ju ARK46G2, Džëlja-Tỉju ARK54B3, Din"|ju ARK61A6, Dod"|ju ARK68B3, Jengalju ARK20V4, Jёn"|ju ARK77V5, Jës"|ju ARK73A4, Žežim"|ju ARK89G5, Zulèb"|ju ARK79V4, Zèr"|ju $\mathrm{ARK}_{3} 8 \mathrm{~V}_{3}, I d z j a s^{\prime \prime} \mid j u \mathrm{ARK}_{51} \mathrm{~B}_{5}$, Izpired'|ju ARK92B2, Iz"jakir"|ju ARK20V2, Iz"ja|ju ARK26G2, Izjas"|ju ARK67V6, Isak-Ju ARK17V8, Ičet'|ju ARK1ooB1, Jovs'|ju ARK48A4, Jr"|ju 67B5, Kart'|ju ARK93V4, Kebilalju ARK19G7, Kerkalju ARK93D4, Ker"|ju ARK5oB1, Kizes'|ju ARK84V3, Kipieva|ju ARK24G1, Kija|ju ARK85V5, Kožim|ju ARK62G3, Kozla|ju ARK61A7, Kol'ju ARK11oG2, Komalju ARK26V3, Kos'|ju ARK49B7, ${ }_{51 V_{5}}, 81 \mathrm{~V}_{5}, 62 \mathrm{G}_{2}, 51 \mathrm{~A}_{5}, 60 \mathrm{~A}_{4}, 26 \mathrm{~B}_{4}, K u z z^{\prime \prime} j u$ ARK89V3, Kuzob"|ju ARK88B2, Kuk"|ju ARK103B4, Kulom"|ju ARK89G4, Kunes"|ju ARK82A2, Kidz'ras"|ju ARK24G3, 42B2, Kidrim"|ju ARK4oV3, Kilèg"|ju ARK84B2, Kin'bož"|ju ARK26V2, Kirnišs'|ju ARK47B6, Kir "|ju ARK71V6, Kǐčan'|ju ARK7oV2, Kèstug|ju ARK4oA2, Lagorta|ju ARK2oG1, Levaja Kirnišs|ju ARK47B6, Levaja Sjuz'|ju ARK54A1, Levij Vožkos'|ju ARK42B4, Levij Grube|ju ARK27V8, Lëk-Vez"|ju ARK78A4, Lëk"|ju ARK24G4, 27A6, Lem"|ju ARK77B5, 85V4, 61B6, Lena|ju ARK61A5, Limbehalju ARK27G5, Lop"|ju ARK102A2, 92A3, 98G2, 79B6, Malaja Veža|ju ARK52V3, Malaja Kos'|ju ARK62G2, Malaja Niedz'|ju ARK19D4, Malaja Pivsjan"|ju ARK51B5, Malaja Pjatombojlju ARK19V5, Malaja Sojlju ARK61V5, Malaja Hal'mer"|ju ARK13V5, Malaja Hojla|ju ARK19G8, Malaja Čiv'|ju ARK75G5, Malaja 
Zarzj|ju ARK18B4, Malva|ju ARK17G6, Malij Kejn"|ju ARK25B7, Mart'|ju ARK96A2, Matkin"|ju ARK61B7, Mes"|ju ARK57V4, Mikit'ju ARK18G4, Mičajju ARK6oB4. Moš"|ju ARK38B3, Mur'|ju ARK67V6, Mirtilju ARK96B3, Nalimalju ARK43G8, Nëb"|ju ARK86B2, Nerim'|ju ARK92A4, Nerka|ju ARK43B8, Ner"|ju ARK27 A7, Nia|ju ARK $34 \mathrm{~V}_{3}$, Niv"|ju ARK51V6, Nižnij Vidz'|ju ARK44V1, Nižnij Kirr"|ju ARK71V6, Nižnjaja Vidz"ë|ju ARK38V1, Nižnjaja Kuz'|ju ARK94B2, Nižnjaja Lèn"|ju ARK46B1, Nižnjaja Sejju ARK47B5, Nijhabar"|ju ARK15V5, Nikita-Sotčem"|ju ARK47A4, Nikon"|ju ARK26A6, Nijalju ARK20A3, Nov'|ju ARK65A6, Niv"|ju 1-2 ARK56G3, Njur'|ju ARK93D4, Njan'vorga|ju ARK28G3, Njar'|ju ARK55A5, Od"|ju ARK79B6, Orda|ju ARK25D5, Oč"|ju ARK46B2, Pal'nik-Ju ARK19D6, 18V4, Pal'|ju ARK91V6, Parnoka|ju ARK27G7, Parč'ju ARK102B2, Pev"|ju ARK75B4, Pernij|ju ARK35B5, Peris'|ju ARK6oA2, Peš"|ju ARK106G3, Piv"|ju ARK99A4, Pok'|ju ARK51A8, Ponan"|ju ARK87B3, Pon"|ju ARK4oA1, Pon"|ju ARK55G4, Pon"|ju ARK25V4, Poskalju ARK24D1, Pot'|ju ARK $72 V_{2}$, Pot'ja|ju ARK85V6, Potèm'ju ARK42G4, Pravaja Oč"|ju ARK46B1, Kinn'bož|ju ARK26V2, Puris'|ju ARK69B 4, Pivsjan"|ju ARK51B5, Pil'|ju ARK50G3, Pitiri"|ju ARK51G6, Ras"|ju ARK 71 V6, 72V1, 91V5, Ruč"|ju ARK88V1, 18G4, 19G5, Saljuku|ju ARK17G6, Sar"|ju ARK 31 G8, 92A1, Severnaja Pes"|ju ARK5oA4, Sev"|ju ARK86G1, Sed"|ju ARK9oV2, 59B5, 98B3, 25V7, 42V3, Semèm"|ju ARK43B8, Sert'ju ARK104B2, Ser'|ju ARK104B2, Sop'|ju ARK75G4, Sord"|ju 68G2, Srednjaja Kuz'|jug ARK94B2, Srednjaja Moš"|ju ARK38B2, Srednjaja Sejjiu ARK47V5, Staraja Piv"ju ARK10oB1, Siv"|ju ARK26G4, 79A6, Sidbar"|ju ARK84B3, Sis'|ju ARK103B4, Sjuz'|ju ARK54V3, Tablika|ju ARK26V1, Tab'ju ARK6A11, Tal'ma|ju ARK12V4, Tan'|ju ARK20G1, Tar"|ju ARK17G7, Taš"|ju ARK85V5, Tes"|ju ARK52B1, Tojjju ARK56V2, Turun"|ju ARK107V4, Tỉbad"|ju ARK84B3, Tỉb"|ju ARK7oG2, 105G4, Tilalju ARK96A1, Tirbil' 'ju ARK42B3, Tilju ARK6oB2, 40B3, Uvlju ARK51A5, Uip"|ju ARK5oA2, Uk"|ju ARK63a1, Ulis-Koj|ju ARK47V3, Ul'ju ARK41B5, Hajma|ju ARK28G2, Hal'mer"|ju ARK12B3, 13V5, 43V7, Hambod"|ju ARK27G5, Hambol"|ju ARK43A5, Haruta|ju ARK17G7, Hasejju ARK15G8, Hinovejju ARK19B6, Hobeju ARK43V6, Hoseda|ju ARK17G7, Hil'čulju ARK6A6, Čažlju ARK5oB3, Čarka|ju

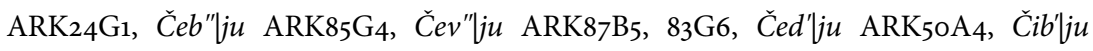

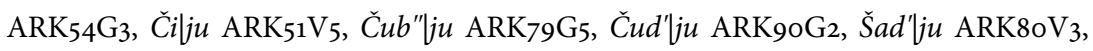
Šar"|ju ARK26B1, Šežim'|ju ARK92B3, Šer"|ju ARK 35 B6, İdzid An'|ju ARK92B2, Idzid Tijju ARK54B 3 , Ėž"jes"|ju ARK87V5, Ėndilju ARK84A3, Ėntjuš"|ju ARK41V6, Južnaja Pes"|ju ARK5oA4, Južnaja Jag"|ju ARK85B4, Jukov"|ju ARK29V4, Jag'|ju ARK85B5, Jaj|ju ARK2oV2, Jan'|ju ARK26G1, Jarakuta|ju ARK25B7, Jaraš"|ju ARK9oG1 


\section{-juk}

Alla|uk AUR38B1, V'|juk AUR18B1, Sjurs|juk AUR17B2, Uz|juk AUR32V1

Parn $\mid u k$ ARK43V5, Juk ARK105 $\mathrm{B}_{5}$

Ki|juk; Bol. \& Mal. AVO40B2, Jerš|uk AVO65G5, Kiljuk AVO40B2, Molljuk AVO38G2 Verh. Miln|juk $\mathrm{AKO}_{35} \mathrm{~A} 2$, Niž. Mil'n|juk $\mathrm{AKO}_{35} \mathrm{~B}_{2}$

Ir|juk $\mathrm{AKiO} 66 \mathrm{~V}_{1}$, Melljuk|ova $\mathrm{AKiO}_{27} \mathrm{~B}_{5}, U z \mid j u k \mathrm{AKiO} 67 \mathrm{G}_{5}$

\section{$-j u g(a)$}

Udmurtia: V'jug AUR24G2, Novaja Bond|juga AUR4oB1

Komi: Aš|uga ARK3oB4, Bol. Lopt|juga ARK 5oG3, Bol. Sar"|juga 26V3, Vad|juga ARK64A2, Važ|uga ARK65V5, Vaz|jug ARK112B2, Jež|uga 29V1, Zirjanskaja Jet|uga 48A3, Kuz|jug ARK112G1, Kirr"|juga ARK25G4, Lap"|juga ARK35B6, Lat'|juga ARK3oD2, Leljug ARK109A4, Lopt|jug ARK65A7, Lopt|juga ARK49G6, Malaja Sar"|juga ARK26V4, Moš"|juga 39B3, Muft|juga ARK49A5, Pav"|juga ARK31G6, Reml|juga ARK48G3, Severnaja Cep'|juga ARK49A5, Črljug ARK108B1, Šarlljug ARK112V1, Šeljug 108B1, Jug ARK102D2, Južnaja Cebiljuga ARK49B5, Sokskij Vazljug AKiO16B1

Vologda: Anjug AVO66G1, Bol. \& Mal. Polljug AVO64A1, Jug; Bol. AVO74V2, Boht|juga $\mathrm{AVO}_{39} \mathrm{~V}_{5}$, Vožduga AVO41V5, Voz|jug AVO 66B2, Vonž|uga AVO25B4, Je jug AVO65B6, Imz|ug AVO6785, Kalč|ug AVO27A6, Kamč|uga $\mathrm{AVO}_{42} \mathrm{~V}_{3}$, Kač|ug $\mathrm{AVO}_{47} \mathrm{G}_{5}$, Kirč|uga $\mathrm{AVO}_{46 V_{3}}$, Kič|uga $\mathrm{AVO}_{25} \mathrm{G}_{5}$, Kič|uga $\mathrm{AVO}_{23} \mathrm{G}_{5}$, Kič|uga $\mathrm{AVO}_{47} \mathrm{~B}_{4}$, Kič|uga $\mathrm{AVO}_{61} \mathrm{~B}_{5}$, Kiljuga AVO17A6, Kol'duga AVO75V5, Kontjug $\mathrm{AVO}_{47} \mathrm{~V}_{5}$, Kortljuga $\mathrm{AVO}_{23} \mathrm{~V}_{5}$, Kost|juga AVO40A2, Kuz|jug AVO67B5, Lant|jug AVO66B2, Levaja Kič|uga AVO45V5, Miz|juga AVO8oA3, Mit|jug AVO65G4, Mit|jug AVO84A3, Nimč|ug AVO46V2, Paž|uga AVO63B6, Pajdug AVO47G4, Pert|uga AVO6oG3, Pič|ug 67B4, Pojduga AVO4oV2, Polevoj Siv'|jug 83B4, Punduga AVO37V5, Piž|ug AVO47G6, Severnij Kalč|ug AVO28A3, Sivč|uga 20A2, Užunduk $\mathrm{AVO}_{37} \mathrm{~V}_{4}$, Uft|juga AVO44A2, Uft|juga AVO21G4, Uft|juga ${ }_{57 \mathrm{~A} 4}$, Šenč|uga AVO18A2, Šefč $\mid u g a \mathrm{AVO}_{40} \mathrm{~B}_{3}$, Jurl|juga $21 \mathrm{~V}_{5}$

Kostroma: Bol. Kort|jug AKO20B3, Bol. Kuzjug AKO43A2, Bol. Parljug AKO8A3, Bol. \& Mal. Pert|jug AKO7B2, Bol. Šort|jug AKO95A2, Verč|uga $\mathrm{AKO}{ }_{105} \mathrm{~B} 1$, Vetl|uga 141A2, Kalljug AKO 47 $\mathrm{B}_{3}$, Karljug $\mathrm{AKO}_{7} \mathrm{~B}_{2}$, Kas $\mid$ ug AKO113A1, Konljug $\mathrm{AKO}_{39} \mathrm{~A}_{2}$, Kortljug 21 $\mathrm{A}_{3}$, Koč|uga AKO157A2, Kuz|jug AKO4332, Lavd|ug AKO62 $\mathrm{A}_{3}$, Lupt|jug $\mathrm{AKO}_{71} \mathrm{~B}_{3}$, Mal. Kortljug AKO44B1, Mal. Parljug AKO22A2, Mal. Solljug AKO6oB1, Matljug AKO8B3, Mič|ug AKO40A1, Norljug AKO47A1, Nočnoj Portjug AKO64A2, Njurljug AKO22A3, 
Njur|jug AKO91B2, Peč|uga AKO99833, Pič|uga $\mathrm{AKO}_{78} \mathrm{~A}_{1}$, Port|jug $\mathrm{AKO} 63 \mathrm{~B}_{1}$, Puč|uga $\mathrm{AKO6oB2}$, Piščlug $\mathrm{AKO}$, Rjund|jug $\mathrm{AKO}_{70} \mathrm{~B}_{2}$, Sondljuga $\mathrm{AKO}_{109 \mathrm{~A}_{3}}$, Suh. Kalljug $\mathrm{AKO}_{71 \mathrm{~A} 2}$, Tolšč|uga $\mathrm{AKO}_{33} \mathrm{~B} 2$, Už|uga $\mathrm{AKO} 61 \mathrm{~A}_{1}$, Šort|jug $\mathrm{AKO}_{70} \mathrm{~A}_{3}$, Jug AKO173A1.

Kirov: Ač|ug $\mathrm{AKiO}_{23} \mathrm{~B} 5$, Bol. Murd|jug $\mathrm{AKiO}_{35} \mathrm{~B}_{5}$, Bol. Norljug $\mathrm{AKiO}_{22} \mathrm{~V}_{3}$, Bol. \& Mal. Njurljug AKO96B2-3, Bol. Šeljug AKiO15A5, Bol. Šiljug AKiO13V5, Vaz|jug AKiO15 B, Verljug AKiO15B5, Sev. Parljug AKO9A2, Kič|ug AKiO13 D5, Kuz|jug AKiO15V6, Laptjug $\mathrm{AKiO}_{22} \mathrm{~V}_{3}$, Londljug $\mathrm{AKiO} 26 \mathrm{~B} 2$, Mat|jug $\mathrm{AKiO}_{24} \mathrm{~V}_{1}$, Mat|jug AKiO24G1, Mat|juga $\mathrm{AKiO}_{53} \mathrm{~V}_{5}$, Murdljug $\mathrm{AKiO}_{35} \mathrm{~V}_{5}$, Norljug $\mathrm{AKiO}_{14} \mathrm{G}_{4}$, Parljug $\mathrm{AKiO}_{24} \mathrm{~V}_{2}$, Pinjug $\mathrm{AKiO}_{13} \mathrm{D}_{5}$, Sord|uk AKiOV 4, Sorm|uk AKiO59B4, Staraja Pin|juga AKiO16G2, Han|jug $\mathrm{AKiO}_{13} \mathrm{~V}_{4}$, Črljug AKiO13D6, Čurm|ug AKiO40G1, Šeljug AKiO13G5, Šubr|jug Severnij AKiO15V6, Šubr|jug AKiO15G6

Nižnij-Novgorod: Kolljuga AKO121A2, Piž|ug N12, Setč|uga N4, Jug N45

Arkhangel: Jelljuga V6, Kidljuga V9, Puht|juga B6, Sivčuga G7, Uftjuga G7, Uft|juga V11, Vajm|uga A5, Ver|juga V8, Voljuga V8, Je|juga G5, Jer|juga V4, Jež|uga G5, Jež|juga V4, Ježljuga Zirjanskaja G6, Loft|juga V5, Mud'|juga $\mathrm{G}_{3}$, Nemn|juga $\mathrm{V}_{4}$, Ner'|juga $\mathrm{V}_{5}$, Oš| uga V5, Ot|juga V4, Urz|uga; Bol. \& Mal. G2. 